\title{
Use of Nitrification Inhibitor DMPP to Improve Nitrogen Uptake Efficiency in Citrus Trees
}

\author{
Belén Martínez-Alcántara ${ }^{1}$, Ana Quiñones ${ }^{1}$, Carolina Polo $^{1}$, Eduardo Primo-Millo ${ }^{1} \&$ Francisco Legaz ${ }^{1}$ \\ ${ }^{1}$ Citricultura y Producción Vegetal, Instituto Valenciano de Investigaciones Agrarias, Spain \\ Correspondence: Belén Martínez-Alcántara, Citricultura y Producción Vegetal, Instituto Valenciano de \\ Investigaciones Agrarias, Spain. Tel: 34-963-424-000. Email: martinez_belalc@gva.es
}

Received: August 13, 2012 Accepted: September 25, 2012 Online Published: January 15, 2013

doi:10.5539/jas.v5n2p1 URL: http://dx.doi.org/10.5539/jas.v5n2p1

\begin{abstract}
In citrus orchards, nitrogen uptake efficiency (NUE) is between 40 to $60 \%$ where any excess of nitrate is subjected to leaching below the rooting zone. The compound, 3,4-dimethylpyrazole phosphate (DMPP) inhibits the nitrification process in soil thus reducing/delaying nitrate leaching. The objective of this study was to evaluate the performance of DMPP added to ammonium sulphate (AS+DMPP), compared to ammonium sulphate (AS) and calcium-potassium nitrate (CPN), in fertigation of bearing orange trees grown outdoors in drainage lysimeters. Fertilizers were ${ }^{15} \mathrm{~N}$-labeled to trace $\mathrm{N}$ through soil-plant-drainage system. Soil was sampled monthly from April to December and trees were destructively harvested in December. In trees fertilized with AS+DMPP, increased biomass was observed with a more profuse development of root system and higher fruit yield. Fertilizer ${ }^{15} \mathrm{~N}$ uptake significantly increased with DMPP addition. In AS+DMPP amended soils, increased values of $\mathrm{NH}_{4}^{+}{ }^{+}{ }^{15} \mathrm{~N}$ and lower $\mathrm{NO}_{3}^{-}-\mathrm{N}$ concentrations were recorded from April to June as evidence of the inhibitory effect of DMPP on the nitrification process during this period. In CPN and AS fertilized soils, ${ }^{15} \mathrm{~N}$ losses in drainage solutions represented $9-10 \%$ of the fertilizer supplied whereas less than $3 \%$ was leached when DMPP was added. At the end of the cycle, highest NUE was recorded in the AS+DMPP treatment (69\%), while CPN and AS had lower values (61\% and 54\%, respectively). Therefore, the use of DMPP enables a more efficient utilization of the fertilizer-N in citrus trees, minimizing the risk of nitrate- $\mathrm{N}$ pollution in groundwater. However, DMPP supply should be considered during spring fertilization, since high temperatures of summer months significantly reduced its activity.
\end{abstract}

Keywords: NUE, leaching losses

\section{Introduction}

About 85-90 million metric tonnes of nitrogenous fertilizers are added to the soil worldwide annually (Good et al., 2004). However, it has been estimated that $50-70 \%$ of this $\mathrm{N}$ is lost (Hodge et al., 2000). Nitrate leaching is considered to be one of the most important mechanisms of N losses from soils (Shen et al., 2003), with consequence of the low fertilizer-N uptake efficiency (NUE), and also contributes to nitrate pollution of groundwater (Lyle \& Richard, 1997; Xing \& Zhu, 2000; Li et al., 2003; Camargo \& Alonso, 2006). For economic and ecological reasons, an increase in NUE continues to be the main objective of N-related research (Hirel et al., 2007).

In a well-managed citrus orchard, where irrigation is correctly timed to avoid excessive leaching and where fertilizer applications are applied appropriately, NUE has been estimated to be between 40 to $60 \%$ (Morgan \& Hanlon, 2006). Most fertilizer $\mathrm{N}$ applied to soils is in the form of ammonium, or ammonium producing compounds such as urea, and is usually oxidized rapidly to nitrate by nitrifying microorganisms in soils. The excess of nitrate not used by trees can be subjected to leaching below the rooting zone of citrus (McNeal et al., 1995). Climatic conditions in citrus production zones and traditional cultivation methods favour nitrification of ammonium and, consequently, nitrate-N loss by leaching (Bergström \& Brink, 1986). Research conducted in the last years has led to a significant increase in knowledge for improving citrus trees nutrient efficiency where NUE is influenced by N rate (Feigenbaum et al., 1987; Lea-Cox \& Syvertsen, 1996; Lea-Cox et al., 2001; Syvertsen \& Smith 1996), timing of application (Kubota et al., 1976a \& b; Kato \& Kubota, 1982; Martínez-Alcántara et al., 2012a; Quiñones et al., 2003, 2012), water management (Alva et al., 1998, 2003; Quiñones et al., 2007), the form of $\mathrm{N}$ applied (Cantarella et al., 2003; Mattos et al., 2003), fertilizer splitting (Alva et al., 1998; Morgan et 
al., 2009; Quiñones et al., 2003), soil type (Martínez et al., 2002; Quiñones et al., 2012) and tree phenological growth stage (Martínez-Alcántara et al., 2012b). A greater synchrony between crop demand and nutrient supply becomes a key factor in NUE improvement. Apart from fertilizer timing, another approach to synchronize release of $\mathrm{N}$ from fertilizers with crop need is the use of $\mathrm{N}$ stabilizers, which inhibit nitrification or urease activity, thereby slowing the conversion of the ammonium fertilizer $\mathrm{N}$ to nitrate (Havlin et al., 2005). Retardation of the biological oxidation of ammonium can therefore reduce $\mathrm{N}$ losses due to leaching (Zerulla et al., 2001). Several chemical compounds are capable of retarding this biological oxidation by inhibiting the activity of Nitrosomonas bacteria, responsible for the first step in nitrification. However, on a global scale, only two nitrification inhibitors gained importance for practical use; these are dicyandiamide (DCD) in Europe and, in a limited extent in the US and, nitrapyrin exclusively in the US (Zerulla et al., 2001). Nevertheless, DCD presents several disadvantages, it is too expensive for large-scale use, its efficiency is comparatively too low, so that high application rates are needed (15-30 $\left.\mathrm{kg} \mathrm{DCD} \mathrm{ha}^{-1}\right)$, it is also highly water soluble, and can be leached through the soil profile, thus reducing its efficiency and may also cause phytotoxicity problems (Zerulla et al., 2001). On the other hand, nitrapyrin cannot be added with solid fertilizers due to its high vapour pressure, and being an organic chlorine compounds, its use can result in certain toxicological problems (Trenkel, 1997; Zerulla et al., 2001).

McCarty and Bremner (1989) found that unsubstituted heterocyclic $\mathrm{N}$ compounds containing two adjacent ring $\mathrm{N}$ atoms inhibited nitrification in soil. Among these compounds, 1,2,4-triazole, pyrazole and some substituted pyrazoles exhibited a potent inhibitory activity in soil. The recently developed compound, 3,4-dimethylpyrazole phosphate (DMPP), is very efficient in inhibiting the nitrification process in soil (McCarty, 1999; Serna et al., 2000; Zerulla et al., 2001; Irigoyen et al., 2003; Chaves et al., 2006; Roco \& Blu, 2006; Yu et al., 2007a \& $2007 \mathrm{~b}$ ), is effective at low concentrations (0.5-1.0 kg DMPP ha ${ }^{-1}$ ) and no toxicological or ecotoxicological side-effects have been reported (Zerulla et al., 2001). Thus, DMPP has already been identified by several authors as one of the most efficient nitrification inhibitors (Hatch et al., 2005; Linzmeier et al., 2001; Weiske et al., 2001) and better than the widely used nitrapyrin (Zerulla et al., 2001).

There have been few studies focused on the performance of DMPP in citrus cultivation. Preliminary studies carried out in young citrus trees grown in soil culture in pots, revealed a remarkable effect of DMPP on decreasing $\mathrm{NO}_{3}^{-}-\mathrm{N}$ levels both in soil and in leaching water, as well as an increase in $\mathrm{N}$ uptake of treated plants (Serna et al., 2000). Under field conditions, DMPP resulted in enhanced N and Fe concentrations in spring-flush leaves and also increased the number of fruits per tree (Quiñones et al., 2009). However, NUE in DMPP supplied adult trees has not been quantified since destructive sampling was necessary to examine dry mass and $\mathrm{N}$ partitioning within the tree which is an expensive an time consuming practice. In addition, there is also a lack of information on the $\mathrm{NO}_{3}^{-}-\mathrm{N}$ and $\mathrm{NH}_{4}^{+}-\mathrm{N}$ distribution in the soil profile and the leaching losses when DMPP is supplied with an ammonium fertilizer under drip irrigation conditions. In this context, the objective of this study was to evaluate the performance of the nitrification inhibitor DMPP added to ammonium sulphate, compared to ammonium sulphate (without inhibitor) and calcium-potassium nitrate, all applied in fertigation to bearing orange trees. The study focused on determining i) tree $\mathrm{N}$ uptake and hence, NUE for each treatment, ii) allocation of $\mathrm{N}$ supplied to the different compartments of the plant-soil system, and iii) quantification of $\mathrm{N}$ leaching losses using fertilizers labeled with the stable isotope ${ }^{15} \mathrm{~N}$.

\section{Materials and Methods}

\subsection{Experimental Conditions: Fertilizer and Irrigation Scheduling}

Nine uniform 10-year-old orange trees (Citrus sinensis (L.) Osbeck) c.v. Navelina grafted on Carrizo citrange (Citrus sinensis x Poncirus trifoliata) rootstock were grown outdoors in 9 individual hexagonal drainage concrete lysimeters $\left(3.8 \mathrm{~m}^{2}\right.$ in area, $110 \mathrm{~cm}$ depth). Lysimeters contained approximately $3.5 \mathrm{~m}^{3}$ of a Typic Xerofluvent soil $\left(67.4 \%\right.$ sand, $10.8 \%$ silt, $21.8 \%$ clay; $\mathrm{pH} 7.9$; organic matter content $0.6 \%$; no $\mathrm{CaCO}_{3}$ and a density of $1.35 \mathrm{~kg} \mathrm{~m}^{-3}$ ). At the beginning of the experiment (six years after tree transplanting) tree canopy diameter averaged $2.70 \mathrm{~m}$.

The $\mathrm{N}$ fertilizer rate was $220 \mathrm{~g} \mathrm{~N}_{\text {year }}{ }^{-1} \cdot \operatorname{tree}^{-1}$ based on tree canopy size. Nitrogen was supplied as ammonium sulphate either without or with the nitrification inhibitor 3,4-dimethylpyrazole phosphate (1\% DMPP relative to $\left.\mathrm{NH}_{4}^{+}-\mathrm{N}\right)$, and as calcium nitrate plus potassium nitrate $\left(60 \%\right.$ of $\mathrm{N}$ rate as $\mathrm{Ca}\left(\mathrm{NO}_{3}\right)_{2}$ and $40 \%$ as $\left.\mathrm{KNO}_{3}\right)$. Nitrogen was labelled with an isotopic enrichment of $4 \%$ atom ${ }^{15} \mathrm{~N}$ excess in all treatments. Therefore, an ammonium either without (AS) or with the nitrification inhibitor (AS+DMPP) and nitrate (CPN) source were compared. The fertilizer-N was applied in the irrigation solution (fertigation) and split into 66 applications between March and October. A short wash cycle after injecting the fertilizer moved the fertilizer solution slightly below the ground 
surface after each fertigation event. The experiment design was three treatments with three uniform trees per treatment which were randomized across the experimental area. Trees were drip irrigated, with 4 commercial emitters per tree $\left(4 \mathrm{~L} \cdot \mathrm{h}^{-1}\right)$ to obtain approximately a $33 \%$ wetting area at $20 \mathrm{~cm}$ depth, according to Keller and Karmelli (1974). The amount of water applied to each tree (Table 1) was equivalent to the total seasonal crop evapotranspiration (ETc) (Doorenbos and Pruitt, 1977). The volume of water applied weekly to each tree was calculated using the expression: $\mathrm{ETc}=\mathrm{ET}_{\mathrm{o}} \cdot \mathrm{K}_{\mathrm{c}}$; where $\mathrm{ET}_{\mathrm{c}}$ is crop evapotranspiration; $\mathrm{ET}_{\mathrm{o}}$ is reference crop evapotranspiration under standard conditions and $\mathrm{K}_{\mathrm{c}}$ is a crop coefficient. $\mathrm{ET}_{\mathrm{o}}$ was determined according to Penman-Monteith (Allen et al., 1998) and $\mathrm{K}_{\mathrm{c}}$ was based on the information described by Castel and Buj (1994), it accounts for crop-specific effects on overall crop water requirements and is a function of canopy size and leaf properties. Within each lysimeter, 2 clusters of tensiometers were installed at the 15 and $45 \mathrm{~cm}$ depths. Tensiometers were used to monitor the soil water content and irrigation was scheduled when average matric potential at both depths attained -10 KPa (Parsons, 1989; Smajstrala et al., 1987). Water requirements were met by the rainfall of the entire year $\left(2,616 \mathrm{~L} \cdot\right.$ tree $\left.^{-1}\right)$ plus irrigation water (Table 1$)$. The volume of water supplied $\left(6,390 \mathrm{~L} \cdot\right.$ tree $\left.^{-1}\right)$ was divided into 79 drip applications (one to three times per week). At the bottom of each tank, drainage tubes were connected to cylinders used to collect the surplus drainage water and to determine potential nitrate leaching.

Table 1. Monthly rainfall, irrigation and $\mathrm{N}$ split application along the experiment

\begin{tabular}{|c|c|c|c|c|c|c|c|c|c|c|}
\hline & Mar. & Apr. & May. & Jun. & Jul. & Aug. & Sep. & Oct. & Nov. & Dec. \\
\hline $\mathrm{Temp}_{\text {air }}\left({ }^{\circ} \mathrm{C}\right)$ & 12.8 & 15.5 & 19.4 & 22.5 & 24.6 & 24.8 & 22.0 & 17.4 & 13.2 & 11.2 \\
\hline $\mathrm{R}\left(\mathrm{L} \cdot \mathrm{m}^{2}\right)^{\mathrm{Z}}$ & 60.1 & 21.8 & 17.1 & 20.0 & 0 & 6.4 & 8.7 & 258.5 & 250.5 & 45.2 \\
\hline $\mathrm{R}_{\text {tree }}\left(\mathrm{L} \cdot \operatorname{tree}^{-1}\right)^{\mathrm{Y}}$ & 228.4 & 82.8 & 65.0 & 76.0 & 0.0 & 24.3 & 33.1 & 982.3 & 951.9 & 171.8 \\
\hline Irrigation $\left(L \cdot\right.$ tree $\left.^{-1}\right)$ & 148.6 & 314.4 & 701.2 & 771.2 & $1,127.6$ & $1,343.8$ & $1,001.0$ & 723.3 & 177.8 & 80.6 \\
\hline $\begin{array}{l}\mathrm{N}^{0} \text { irrigations } \\
\text { month }^{-1}\end{array}$ & 2 & 7 & 8 & 12 & 12 & 12 & 9 & 4 & 3 & 2 \\
\hline $\mathrm{N}$ rate $^{\mathrm{X}}(\%)$ & 5 & 10 & 15 & 20 & 20 & 15 & 10 & 5 & & \\
\hline
\end{tabular}

$\mathrm{z}$ : Monthly rainfall per area; ${ }^{\mathrm{Y}}$ : Rainfall per tree $=\mathrm{R} \cdot \mathrm{Ac}$; where Ac is the lysimeter area $\left(3.8 \mathrm{~m}^{2}\right) ;{ }^{\mathrm{X}}$ : Monthly percentage distribution of the total $\mathrm{N}$ rate $\left(220 \mathrm{~g} \mathrm{~N}\right.$ tree $\left.^{-1}\right)$.

\subsection{Soil Sampling and Tree Harvest}

Soil was sampled monthly (from April to December) from 0-20 and 20-40 cm layers using a $4 \mathrm{~cm}$ diameter auger; deeper soil sampling was a difficult operation and could not be done without significantly disturbing soil structure in lysimeters. Soil sample cores were taken at $20 \mathrm{~cm}$ from the emitter; sampling always occurred 2 days after the latest $\mathrm{N}$ application. The sampling holes were plugged with a soil of the same characteristics and flagged to avoid repeated sampling from the same spot. On 11th December trees were destructively harvested and soil was sampled to the bottom of the lysimeter in $20 \mathrm{~cm}$ layer increments $(0-20,20-40,40-60$, and 60-90 $\mathrm{cm}$ ); three representative samples from each layer were taken. Soil samples were air-dried at room temperature, dry-weighed, crushed through a $2 \mathrm{~mm}$ screen and stored for analysis. The mineral nitrogen $\left(\mathrm{NO}_{3}^{-}-\mathrm{N}\right.$ and $\left.\mathrm{NH}_{4}^{+}-\mathrm{N}\right)$ was measured (Raigón et al., 1992) with flow-injection analysis (FIAstar 5000, Foss Tecator, Höganäs, Sweden) in soil extracts $(2 \mathrm{M} \mathrm{KCl})$ and drainage water. To determine ${ }^{15} \mathrm{~N} /{ }^{14} \mathrm{~N}$ isotopic composition of mineral fractions, soil $\mathrm{KCl}$ extracts were steam-distilled (2200 Kjeltec, Distillation Unit, Foss Tecator, Höganäs, Sweden); $\mathrm{NH}_{4}^{+}-{ }^{15} \mathrm{~N}$ and $\mathrm{NO}_{3}^{-}{ }_{-}{ }^{15} \mathrm{~N}$ were recovered in boric acid (Bremner, 1996). Aliquots were acidified with $0.32 \mathrm{~N}$ $\mathrm{H}_{2} \mathrm{SO}_{4}$ and reduced to dryness in an oven (P Selecta, Barcelona, Spain) at $65^{\circ} \mathrm{C}$ before analysis using an Isotope Ratio Mass Spectrometer (Delta Plus, Thermo Finnigan, Bremen, Germany).

To evaluate fertilizer $\mathrm{N}$ uptake, trees were cut down at the soil surface $\left(11^{\text {th }}\right.$ December) and separated into fruits, leaves and twigs of the current year, leaves of previous years, and trunk plus branches, at the end of the cycle $\left(24^{\text {th }}\right.$ November $)$. All soil layers were excavated and coarse and fine roots $(<2 \mathrm{~mm}$ diameter $)$ were separated by hand. In order to estimate the fibrous roots remaining in the soil, three soil samples were taken in each layer and sifted through a $2 \mathrm{~mm}$ mesh sieve to remove the rest of the fibrous roots. All fractions were weighed and sampled to quantify total dry biomass. Samples were washed in non ionic detergent solution followed by several rinses in deionised water, weighed, frozen into liquid nitrogen, freeze-dried (Lyoalfa, Telstar, Barcelona, Spain), 
dry-weighed and ground in a water refrigerated mill (IKA M 20, IKA Labortechnik, Staufen, Germany) before analysis. With the aim of assessing fertilizer-N losses associated with abscised parts, tree litter (old leaves, flowers, petals, calyces, and fruitlets) was caught in nets from onset of flowering ( $\left(1^{\text {st }}\right.$ April) until the end of fruit setting ( $4^{\text {th }}$ July). Abscised organs were dried, weighed, milled and stored for subsequent $\mathrm{N}$ and ${ }^{15} \mathrm{~N}$ analysis. Determinations of total $\mathrm{N}$ concentration and ${ }^{15} \mathrm{~N}$ abundance in vegetal samples were performed with an Elemental Analyzer (NC 2500 Thermo Finnigan, Bremen, Germany) coupled to an Isotope Ratio Mass Spectrometer (Delta Plus, Thermo Finnigan, Bremen, Germany).

\subsection{Calculations and Statistical Analysis}

Based on data of dry weight (DW, g) and total $\mathrm{N}$ concentration $(\mathrm{N} \%, \mathrm{w} / \mathrm{w})$ for each plant compartment, $\mathrm{N}$ content was calculated: $\mathrm{N}(\mathrm{g})=\mathrm{N} \% \cdot \mathrm{DW} \cdot 100^{-1}$. The ${ }^{15} \mathrm{~N}$ content per plant compartment was calculated as follows: ${ }^{15} \mathrm{~N}_{\text {plant compartment }}(\mathrm{mg})=\mathrm{N} \% \cdot \mathrm{DW} \cdot \mathrm{atom} \%{ }^{15} \mathrm{~N}$ excess $10^{-1}$; where atom $\%{ }^{15} \mathrm{~N}$ excess was calculated by subtracting the natural abundance of ${ }^{15} \mathrm{~N}$ from the atom $\%{ }^{15} \mathrm{~N}$ in each sample. The natural abundance of ${ }^{15} \mathrm{~N}$ was considered to be the abundance of atmospheric $\mathrm{N}_{2}, 0.3663$ atom \%, according to the International Atomic Energy Agency (IAEA, 1983). Total plant recovery of applied ${ }^{15} \mathrm{~N}$-fertilizer represents the proportion of applied ${ }^{15} \mathrm{~N}$ that is taken up by the tree and embodies its fertilizer-nitrogen use efficiency (NUE). NUE was calculated by the formula: NUE $=100 \cdot{ }^{15} \mathrm{~N}$ taken up whole plant $(\mathrm{mg}) /{ }^{15} \mathrm{~N}_{\text {fertilizer }}(\mathrm{mg})$; where ${ }^{15} \mathrm{~N}$ taken up $p_{\text {whole plant }}(\mathrm{mg})=\sum^{15} \mathrm{~N}(\mathrm{mg})$ plant compartment. The amount of ${ }^{15} \mathrm{~N}$ recovered per soil layer in each soil $\mathrm{N}$ fraction $\left(\mathrm{NO}_{3}^{-}-{ }_{-}{ }^{2} \mathrm{~N}, \mathrm{NH}_{4}^{+}-{ }^{15} \mathrm{~N}\right)$ was determined as follows: ${ }^{15} \mathrm{~N}_{\text {soil } \mathrm{N} \text { fraction }}(\mathrm{mg})=\mathrm{N}_{\text {soil fraction }}\left(\mathrm{mg} \mathrm{N} \cdot \mathrm{kg}^{-1}\right.$ soil) soil layer $\mathrm{DW}(\mathrm{kg}) \cdot$ atom $\%{ }^{15} \mathrm{~N}$ excess $\cdot 100^{-1}$. Leaching losses were calculated on the basis of their concentrations in the leachate collected from each lysimeter and the volume of the leachate. Data were subjected to ANOVA to test for significant differences between treatments. When $\mathrm{F}$ ratio was significant, means were separated by least significant difference test (LSD) at the 0.05 probability level, using SAS software (Statistical Analysis System Institute Inc., Cary, North Carolina, USA). The ratios of the amount of ${ }^{15} \mathrm{~N}$ allocated in aboveground to that in belowground organs were compared by Student's t-test $(\mathrm{p}<0.05)$.

\section{Results}

\subsection{Biomass Partitioning}

Table 2 shows mean dry biomass of the whole tree and its distribution among different organs. Highest tree biomass was obtained in trees fertilized with AS+DMPP, while lower values were recorded in trees receiving AS or CPN. The higher fruit yield and coarse root development in presence of the nitrification inhibitor, with values that exceeded those recorded not only in AS but also in CPN trees, were responsible for this increased biomass of AS+DMPP trees. Moreover, a significantly lower development in new flush leaves and twigs, aerial woody organs (trunk and branches) and fibrous roots of AS was observed when compared to AS+DMPP fed trees, which also contributed to the differences recorded in total dry weight. However, the opposite pattern was observed in abscised organs (Table 2), where significantly lower values were found in the AS+DMPP treatment if compared to AS trees; CPN treated trees exhibited intermediate non-significant values.

Table 2. Dry biomass partitioning in ammonium sulphate without (AS) or with the nitrification inhibitor DMPP (AS+DMPP) and calcium-potassium nitrate (CPN) supplied citrus trees

\begin{tabular}{llllllll}
\hline & AS & \multicolumn{2}{c}{ AS+DMPP } & CPN & & ANOVA $^{\mathrm{Z}}$ \\
\hline Fruits & $14.908^{\mathrm{Y}}$ & $\mathrm{b}$ & 17.780 & $\mathrm{a}$ & 13.664 & $\mathrm{~b}$ & $* *(0.006)$ \\
New flush leaves and twigs $\mathrm{X}$ & 3.652 & $\mathrm{~b}$ & 5.153 & $\mathrm{a}$ & 4.342 & $\mathrm{ab}$ & $*(0.036)$ \\
Old leaves & 4.627 & & 4.783 & & 4.948 & & ns $(0.878)$ \\
Trunk and branches & 14.164 & $\mathrm{~b}$ & 18.101 & $\mathrm{a}$ & 18.953 & $\mathrm{a}$ & $* * *(0.0001)$ \\
Coarse roots & 6.976 & $\mathrm{c}$ & 11.640 & $\mathrm{a}$ & 8.876 & $\mathrm{~b}$ & $* *(0.002)$ \\
Fibrous roots & 2.362 & $\mathrm{~b}$ & 4.087 & $\mathrm{a}$ & 2.921 & $\mathrm{ab}$ & $*(0.025)$ \\
TOTAL TREE & 46.689 & $\mathrm{c}$ & 61.544 & $\mathrm{a}$ & 53.703 & $\mathrm{~b}$ & $* * *(<0.001)$ \\
Abscised organs $^{\mathrm{W}}$ & 5.970 & $\mathrm{a}$ & 3.083 & $\mathrm{~b}$ & 5.499 & $\mathrm{ab}$ & $*(0.022)$ \\
\hline
\end{tabular}

$\mathrm{Z}$ : $\mathrm{P}$-value is indicated between parentheses. Significant effects of treatments are given at ${ }^{*} \mathrm{P} \leq 5 \%,{ }^{* *} \mathrm{P} \leq 1$ and ${ }^{* * *} \mathrm{P} \leq 0.1 \%$ in each treatment; ns $(\mathrm{P}>5 \%)$, not significant. ${ }^{\mathrm{Y}}$ : Each value is an average of three trees. ${ }^{\mathrm{X}}$ : Leaves and twigs of autumn+summer and spring flush, respectively. ${ }^{\mathrm{W}}$ : Old leaves, flowers, petals, calyces, ovaries and fruitlets collected in nets between April and July. 


\subsection{Total $N$ and Fertilizer $N$ Uptake in Plant Tissues}

Significantly higher $\mathrm{N}$ concentrations were found in aerial woody organs (trunk and branches) in AS+DMPP treatment, whereas similar values were found in AS and CPN trees (Table 3). Although no significant differences were found in the $\mathrm{N}$ concentrations of the rest of the organs, variations obtained in the biomass of the different plant compartments (Table 2) led to significant differences in total $\mathrm{N}$ content among treatments. Thus, $\mathrm{N}$ content in total tree followed the same pattern than that observed in dry biomass (AS+DMPP $>\mathrm{CPN}>\mathrm{AS}$ ). Fruits of AS+DMPP treatment accumulated higher $\mathrm{N}$ than those in CPN as a consequence of the increased yield from the AS+DMPP treatment. Aerial woody organs of AS+DMPP also exhibited the highest $\mathrm{N}$ content, while similarly lower values were observed in trunk and branches of AS and CPN trees. Moreover, a lower N content was found in root system (coarse and fibrous roots) of AS amended trees, if compared to AS+DMPP, while CPN showed intermediate non-significant values. In abscised organs, increased $\mathrm{N}$ concentrations where observed in AS+DMPP and CPN treatments compared to AS treated trees. Nevertheless, the reverse pattern was found in N content in tree litter of AS+DMPP and AS trees, as a consequence of the differences recorded in the biomass of abscised biomass of both treatments (Table 2).

Table 3. Nitrogen concentrations in different organs of ammonium without (AS) or with the nitrification inhibitor DMPP (AS+DMPP) and calcium-potassium nitrate (CPN) supplied citrus trees

\begin{tabular}{|c|c|c|c|c|c|c|c|c|c|c|c|c|c|c|}
\hline \multirow[b]{3}{*}{ Fruits } & \multicolumn{7}{|c|}{$\mathrm{N}(\%)$} & \multicolumn{7}{|c|}{$\mathrm{N}$ content $(\mathrm{mg})$} \\
\hline & \multicolumn{2}{|l|}{ AS } & \multicolumn{2}{|c|}{ AS+DMPP } & \multicolumn{2}{|c|}{$\mathrm{CPN}$} & \multirow{2}{*}{$\frac{\text { ANOVA }}{\text { ns }(0.655)}$} & \multicolumn{2}{|l|}{ AS } & \multicolumn{2}{|c|}{ AS+DMPP } & \multicolumn{2}{|l|}{$\mathrm{CPN}$} & \multirow{2}{*}{$\begin{array}{l}\text { ANOVA }^{\mathrm{Z}} \\
* *(0.013)\end{array}$} \\
\hline & $0.84^{\mathrm{Y}}$ & & 0.80 & & 0.84 & & & 125,425 & $\mathrm{ab}$ & 142,090 & $\mathrm{a}$ & 114,318 & $\mathrm{~b}$ & \\
\hline New flush leaves and twigs ${ }^{\mathrm{X}}$ & 2.38 & & 2.40 & & 2.27 & & $\mathrm{~ns}(0.411)$ & 86,861 & & 123,595 & & 98,555 & & $\mathrm{~ns}(0.118)$ \\
\hline Old leaves & 2.24 & & 2.41 & & 2.36 & & ns $(0.402)$ & 103,850 & & 115,334 & & 116,923 & & ns $(0.387)$ \\
\hline Trunk and branches & 0.82 & $\mathrm{~b}$ & 1.07 & a & 0.79 & $\mathrm{~b}$ & $*(0.031)$ & 115,562 & $\mathrm{~b}$ & 193,097 & a & 149,464 & $\mathrm{~b}$ & $* *(0.009)$ \\
\hline Coarse roots & 0.93 & & 1.04 & & 1.02 & & $\mathrm{~ns}(0.460)$ & 64,761 & $\mathrm{~b}$ & 120,611 & $\mathrm{a}$ & 90,361 & $\mathrm{ab}$ & $* *(0.015)$ \\
\hline Fibrous roots & 1.81 & & 1.73 & & 1.82 & & ns $(0.714)$ & 42,665 & $\mathrm{~b}$ & 70,732 & $\mathrm{a}$ & 53,153 & $a b$ & $*(0.049)$ \\
\hline TOTAL TREE & 1.15 & & 1.24 & & 1.16 & $\mathrm{~b}$ & $\mathrm{~ns}(0.278)$ & 539,124 & $\mathrm{c}$ & 765,459 & $\mathrm{a}$ & 622,775 & $\mathrm{~b}$ & $* * *(<0.001)$ \\
\hline Abscised organs ${ }^{\mathrm{W}}$ & 1.41 & $\mathrm{~b}$ & 1.68 & $\mathrm{a}$ & 1.61 & $\mathrm{a}$ & $*(0.044)$ & 84,313 & $\mathrm{a}$ & 51,640 & $\mathrm{~b}$ & 88,541 & $\mathrm{a}$ & $* * *(<0.001)$ \\
\hline
\end{tabular}

$\overline{\mathrm{Z}, \mathrm{Y}, \mathrm{X}, \mathrm{W}}$ : See Table 2.

Fertilizer $\mathrm{N}$ source led to remarkable differences in ${ }^{15} \mathrm{~N}$ enrichment $\left(\%{ }^{15} \mathrm{~N}\right.$ excess $)$ in almost all tree compartments (Table 4) but a different pattern in aboveground and belowground organs was observed. Highest labelling values of fruit, new flush leaves and twigs, and old leaves were recorded in CPN amended trees, and similar lower values were obtained in AS fertilized trees with or without inhibitor (AS and AS+DMPP). However, AS+DMPP trees had the highest ${ }^{15} \mathrm{~N}$ enrichments in fibrous roots, followed by CPN trees. AS fine roots, however, had the lowest enrichments. Fertilizer labelling allowed the quantification of its uptake enabling the identification of the fertilizer- $\mathrm{N}$ allocated in each plant compartment with no interferences with other $\mathrm{N}$ sources (native soil, irrigation water or tree reserve remobilization). Maximum fertilizer-N uptake occurred in AS+DMPP supplied trees which were $16 \%$ and $38 \%$ higher than uptake in CPN and AS fertilized trees, respectively (Table 4). Fertilizer-N allocated to the root system was mainly responsible for the differences set in whole tree $\mathrm{N}$ uptake. The amount of fertilizer- $\mathrm{N}$ accumulated in the root system (coarse plus fine roots) of AS+DMPP supplied trees was 2-fold greater than the average in CPN and AS treatments (which showed no differences). In above ground organs, new flush leaves and twigs of AS+DMPP supplied trees accumulated higher fertilizer-N than those of AS. In trunk plus branches, fertilizer- $\mathrm{N}$ increased in the order of $\mathrm{AS}<\mathrm{CPN}<\mathrm{AS}+\mathrm{DMPP}$. It is remarkable, that a lower amount of fertilizer-N was lost in abscised organs of AS+DMPP trees when compared to AS or CPN supplied trees, which showed similar higher contents. The ratio of the amount of fertilizer- ${ }^{15} \mathrm{~N}$ allocated in aboveground organs to that in belowground organs (A:B; Table 4) was much lower in AS+DMPP trees than in CPN and AS which indicated that fertilizer N accumulated preferentially in the root system of AS+DMPP trees whereas the reverse occurred in the other treatments. 
Table 4. Labelled nitrogen in excess and fertilizer-N uptake in different organs of ammonium without (AS) or with the nitrification inhibitor DMPP (AS+DMPP) and calcium-potassium nitrate (CPN) supplied citrus trees

\begin{tabular}{|c|c|c|c|c|c|c|c|c|c|c|c|c|c|c|}
\hline \multirow[b]{3}{*}{ Fruits } & \multicolumn{7}{|c|}{${ }^{15} \mathrm{~N}$ excess $(\%)$} & \multicolumn{7}{|c|}{ Fertilizer-N uptake (mg) } \\
\hline & \multicolumn{2}{|l|}{ AS } & \multicolumn{2}{|c|}{ AS+DMPP } & \multicolumn{2}{|c|}{$\mathrm{CPN}$} & \multirow{2}{*}{$\frac{\text { ANOVA }}{* *(0.007)}$} & \multirow{2}{*}{\multicolumn{2}{|c|}{$\begin{array}{r}\text { AS } \\
33,271\end{array}$}} & \multicolumn{2}{|c|}{ AS+DMPP } & \multicolumn{2}{|l|}{$\mathrm{CPN}$} & \multirow{2}{*}{$\frac{\mathrm{ANOVA}^{\mathrm{Z}}}{\mathrm{ns}(0.249)}$} \\
\hline & $1.06^{\mathrm{Y}}$ & $\mathrm{b}$ & 1.01 & $\mathrm{~b}$ & 1.25 & $\mathrm{a}$ & & & & 35,773 & & 35,708 & & \\
\hline New flush leaves and twigs $\mathrm{x}^{\mathrm{X}}$ & 1.01 & $\mathrm{~b}$ & 1.03 & $\mathrm{~b}$ & 1.16 & a & $*(0.048)$ & 21,900 & $\mathrm{~b}$ & 31,686 & $\mathrm{a}$ & 28,675 & $\mathrm{ab}$ & $*(0.034)$ \\
\hline Old leaves & 0.76 & $\mathrm{~b}$ & 0.71 & $\mathrm{~b}$ & 0.85 & $\mathrm{a}$ & $* *(0.013)$ & 19,606 & & 20,400 & & 24,829 & & ns $(0.167)$ \\
\hline Trunk and branches & 0.60 & & 0.55 & & 0.57 & & ns (0.399) & 17,378 & $\mathrm{c}$ & 26,320 & $\mathrm{a}$ & 21,125 & $\mathrm{~b}$ & $* *(0.006)$ \\
\hline Coarse roots & 0.35 & & 0.45 & & 0.37 & & ns $(0.194)$ & 5,675 & $\mathrm{~b}$ & 13,621 & $\mathrm{a}$ & 8,445 & $\mathrm{~b}$ & $* *(0.013)$ \\
\hline Fibrous roots & 0.85 & $\mathrm{c}$ & 1.13 & $\mathrm{a}$ & 0.68 & $\mathrm{~b}$ & $* * *(<0.001)$ & 9,038 & $\mathrm{~b}$ & 20,023 & $\mathrm{a}$ & 9,029 & $\mathrm{~b}$ & $* *(0.014)$ \\
\hline TOTAL TREE & 0.79 & & 0.77 & & 0.82 & & ns $(0.521)$ & 106,868 & $\mathrm{c}$ & 147,823 & $\mathrm{a}$ & 127,811 & $\mathrm{~b}$ & $* *(0.012)$ \\
\hline Abscised organs ${ }^{W}$ & 0.51 & $\mathrm{~b}$ & 0.31 & $\mathrm{c}$ & 0.65 & a & $* *(0.003)$ & 10,737 & $\mathrm{a}$ & 4,066 & $\mathrm{~b}$ & 14,3880 & $\mathrm{a}$ & $* * *(<0.001)$ \\
\hline $\mathrm{A}: \mathrm{B}$ ratio & & & & & & & & 6.3 & $\mathrm{a}$ & 3.4 & $\mathrm{~b}$ & 6.3 & a & $* * *(<0.001)$ \\
\hline
\end{tabular}

$\overline{\mathrm{Z}, \mathrm{Y}, \mathrm{X}, \mathrm{W}}$ : See Table 2.

Table 5. Percentage recovery of fertilizer- ${ }^{15} \mathrm{~N}$ in different compartments of the plant-soil system

\begin{tabular}{lllllllll}
\hline & AS & & AS+DMPP & CPN & & ANOVA $^{Z}$ \\
\hline Plant tissues (NUE) & $54.2^{\mathrm{Y}}$ & $\mathrm{c}$ & 69.4 & $\mathrm{a}$ & 61.2 & $\mathrm{~b}$ & $*(0.041)$ \\
Soil & & & & & & & \\
Nitrate & 2.5 & $\mathrm{~b}$ & 1.7 & $\mathrm{c}$ & 6.3 & $\mathrm{a}$ & $* *(0.022)$ \\
Ammonium & 10.7 & $\mathrm{a}$ & 11.2 & $\mathrm{a}$ & 2.8 & $\mathrm{~b}$ & $* * *(<0.001)$ \\
Organic & 9.4 & & 8.1 & & 7.9 & & $\mathrm{~ns}(0.822)$ \\
Total soil & 22.6 & $\mathrm{a}$ & 21.0 & $\mathrm{a}$ & 17.0 & $\mathrm{~b}$ & $*(0.037)$ \\
Leaching & 8.7 & $\mathrm{ab}$ & 2.5 & $\mathrm{~b}$ & 10.3 & $\mathrm{a}$ & $* * *(<0.001)$ \\
Total recovery & 86.5 & & 92.9 & & 88.5 & & $\mathrm{~ns}(0.745)$ \\
\hline
\end{tabular}

Z,Y: See Table 2.

\subsection{Nitrate, Ammonium and Organic N-forms in the Soil Profile}

In all soil samples, $\mathrm{NO}_{3}^{-}{ }_{-}^{15} \mathrm{~N}$ concentrations in $0-20 \mathrm{~cm}$ depth of $\mathrm{CPN}$-amended soils were significantly higher than in AS amended soils either with or without DMPP (Figure 1a). The addition of the nitrification inhibitor led to even significantly lower $\mathrm{NO}_{3}^{-}{ }_{-}^{15} \mathrm{~N}$ concentrations than that in the AS treatment from the 2nd until 5th soil sampling. However, from the 6th sampling onwards, similar $\mathrm{NO}_{3}^{-}{ }_{-}{ }^{15} \mathrm{~N}$ concentrations were measured in both the AS and AS+DMPP treatments. In the 20-40 cm depth soil layer (Figure 1b), highest $\mathrm{NO}_{3}^{-}-^{15} \mathrm{~N}$ concentrations were also recorded with CPN fertilization, which peaked on the 5th sampling $\left(0.36 \mathrm{mg} \mathrm{kg} \mathrm{soil}{ }^{-1}\right)$; later on decreased to similar values to that on the 1 st soil sampling $\left(0.12 \mathrm{mg} \mathrm{kg} \mathrm{soil}^{-1}\right)$. Similar to the pattern observed in the upper layer, differences in $\mathrm{NO}_{3}^{-}{ }_{-}{ }^{15} \mathrm{~N}$ concentrations among AS and AS+DMPP treatment increased from the 2nd sampling and remained high until after the 4th sampling.

The highest values of exchangeable $\mathrm{NH}_{4}{ }^{+}-{ }^{15} \mathrm{~N}$ concentrations in the top soil $(0-20 \mathrm{~cm})$ were found in AS+DMPP amended soils (average values of $2 \mathrm{mg} \mathrm{kg} \mathrm{soil}{ }^{-1}$ ), followed by AS (Figure 2a). The most remarkable differences among the AS and AS+DMPP treatments were observed in the 2nd-4th sampling interval. Whereas $\mathrm{NH}_{4}^{+}{ }^{+}{ }^{15} \mathrm{~N}$ concentrations in AS treatment sharply deceased in the 2nd sampling date, addition of DMPP resulted in rather constant values in $\mathrm{NH}_{4}^{+}-{ }^{15} \mathrm{~N}$ concentration in the 1st-6th sampling intervals, as a consequence of the inhibitory effect in the nitrification processes. In CPN treatment, significantly lower values in $\mathrm{NH}_{4}^{+}{ }_{-}{ }^{15} \mathrm{~N}$ concentration were recorded $\left(<0.25 \mathrm{mg} \mathrm{kg} \mathrm{soil}^{-1}\right)$ than those in AS and AS+DMPP treatments which remained almost constant all over the studied period. In the 20-40 cm soil layer (Figure 2b), soils of AS and AS+DMPP showed increasing values along the sampling events, as a consequence of the AS. On the contrary, CPN treated soils, had rather 
uniform values along the experiment $\left(0.04 \mathrm{mg} \mathrm{kg} \mathrm{soil}{ }^{-1}\right.$, on average) clearly below to those of AS and AS+DMPP treatments.

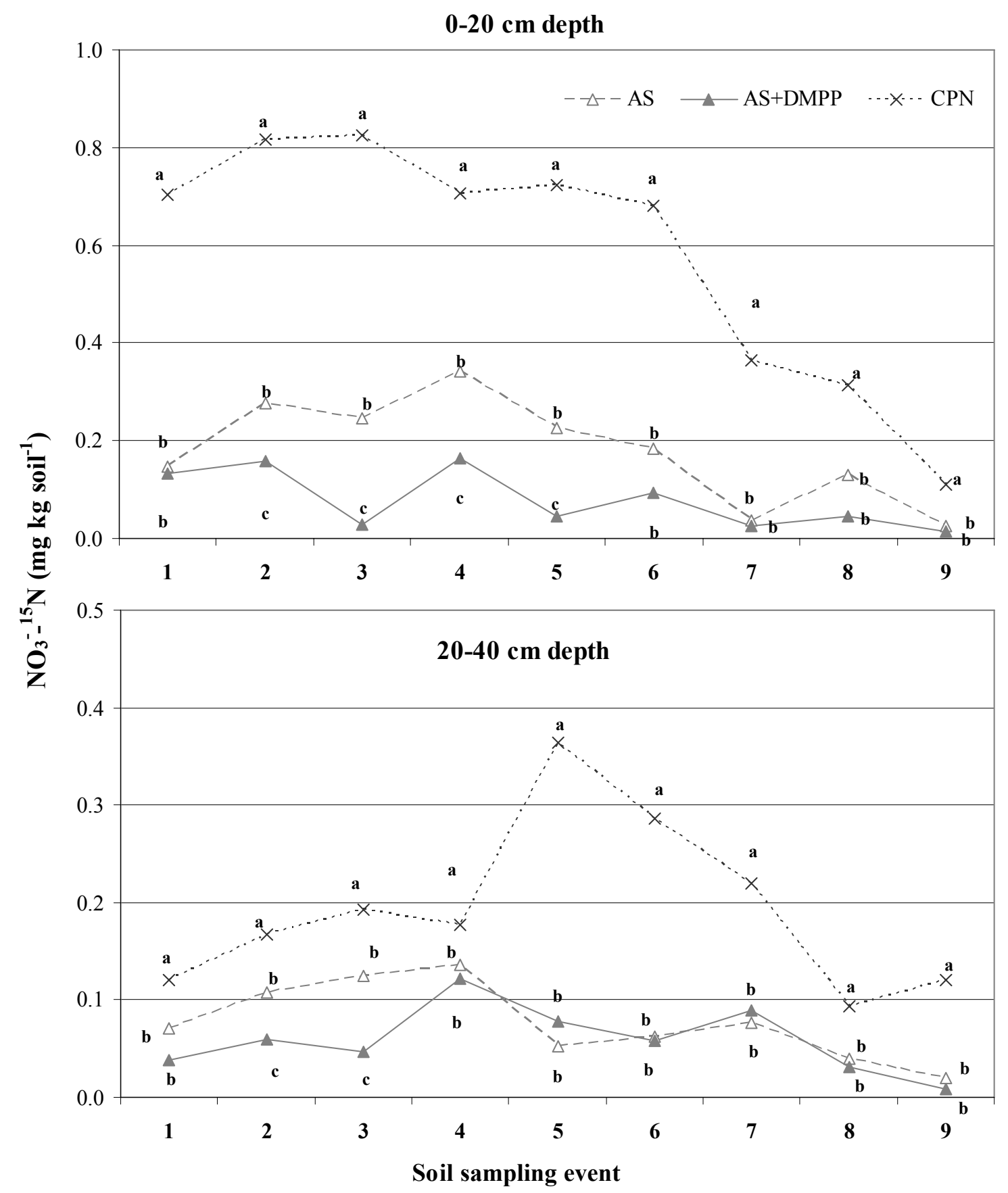

Figure 1. Evolution of fertilizer-N concentration in nitrate fraction in 0-20 and 20-40 cm depth layers of soil profile in ammonium sulphate without (AS) or with DMPP (AS+DMPP) and nitrate (CPN) supplied citrus trees along the assay 


\section{0-20 cm depth}

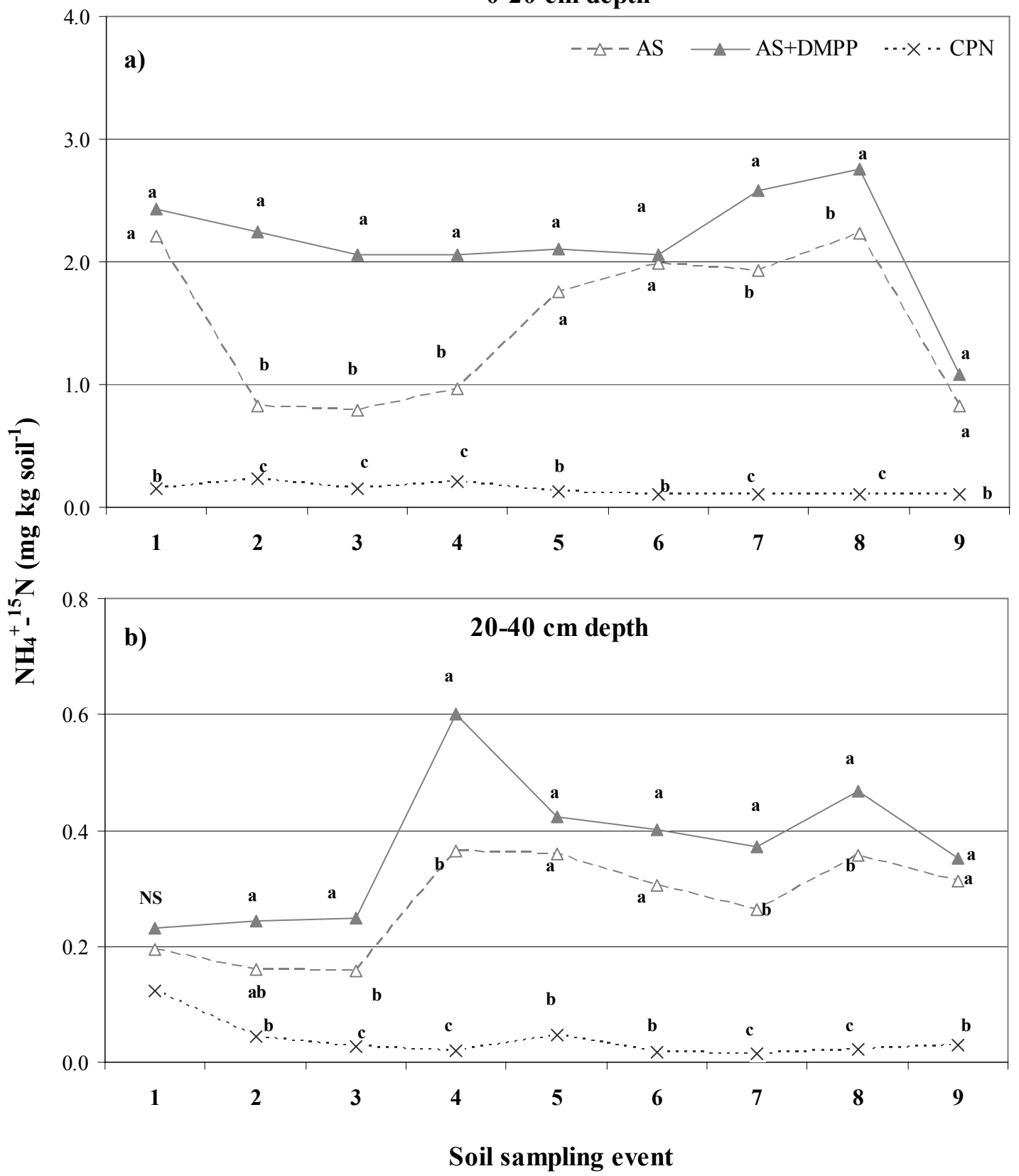

Figure 2. Evolution of fertilizer-N concentration in ammonium fraction in $0-20$ and $20-40 \mathrm{~cm}$ depth layers of soil profile in ammonium sulphate without (AS) or with DMPP (AS+DMPP) and nitrate (CPN) supplied citrus trees along the assay

Fertilizer ${ }^{15} \mathrm{~N}$ immobilized in the organic fraction $\left({ }^{15}\right.$ Norganic) in the upper $0-20 \mathrm{~cm}$ layer (Figure 3a) exhibited an overall increasing trend along the studied period. However, in CPN amended soils which showed the lowest ${ }^{15}$ Norganic values, the amount of ${ }^{15} \mathrm{~N}$ immobilized in the organic fraction continuously increased. In AS and AS+DMPP treatments, values tended to stabilize and even slightly decrease from 6th sampling onwards. This pattern led to non-significant differences at the end of the experiment. The addition of DMPP resulted in higher ${ }^{15}$ Norganic values than that in the AS treatment in some of the soil sampling times. In the $20-40 \mathrm{~cm}$ soil layer, no significant differences were recorded among treatments, which showed an upward trend until 8th sampling (Figure 3b). 

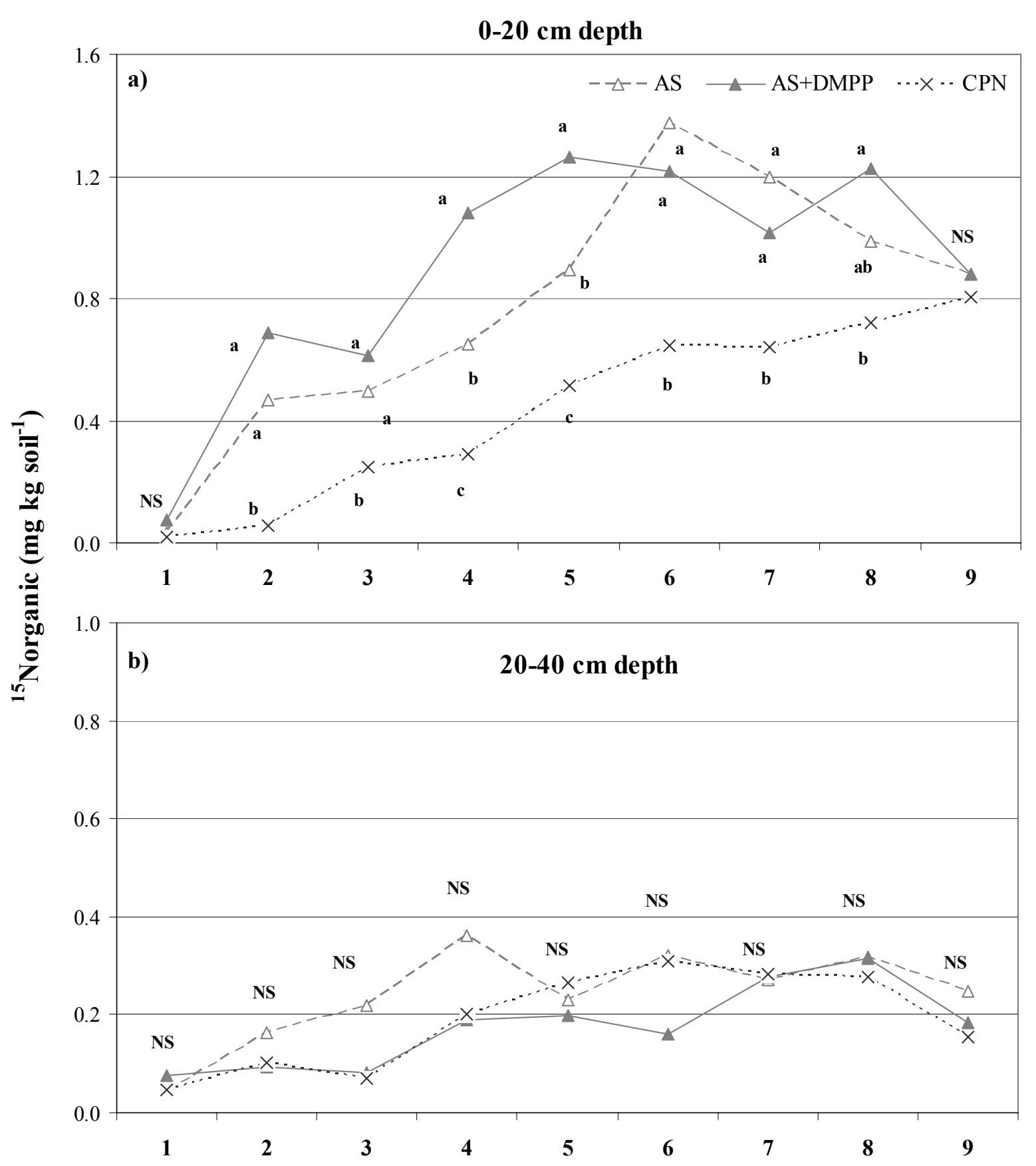

Soil sampling event

Figure 3. Fertilizer nitrogen concentration in soil organic fraction in 0-20 and 20-40 cm depth layers of soil profile in ammonium sulphate without (AS) or with DMPP (AS+DMPP) and nitrate (CPN) supplied citrus trees along the assay

Tree harvest at the end of the cycle allowed a complete summary of the $\mathrm{NO}_{3}^{-}{ }_{-}{ }^{15} \mathrm{~N}, \mathrm{NH}_{4}^{+}-{ }^{15} \mathrm{~N}$ and $\mathrm{Norg}-{ }^{15} \mathrm{~N}$ dynamics in the soil profile (Figure 4). The enhanced $\mathrm{NO}_{3}^{-}{ }_{-}^{15} \mathrm{~N}$ concentrations recorded throughout the study in the upper $40 \mathrm{~cm}$ soil layers of the CPN trees (Figure 1a, 1b) could be also observed in the 40-60 and 60-90 cm soil depths at the end of the cycle. In CPN amended soils, $\mathrm{NO}_{3}{ }_{-}-{ }^{15} \mathrm{~N}$ concentrations across the soil profile were rather uniform; values averaged $0.11 \mathrm{mg} \mathrm{kg} \mathrm{soil}{ }^{-1}$ in the $0-60 \mathrm{~cm}$ soil depth, showing a slight increase at $60-90$ 
cm depth $\left(0.18 \mathrm{mg} \mathrm{kg} \mathrm{soil}{ }^{-1}\right)$. In AS and AS+DMPP treated soils, $\mathrm{NO}_{3}^{-}{ }^{15} \mathrm{~N}$ concentrations markedly increased from $40 \mathrm{~cm}$ depth downwards. At $60-90 \mathrm{~cm}$ depth minimum $\mathrm{NO}_{3}^{-}{ }^{-15} \mathrm{~N}$ concentration was observed in the AS+DMPP treatment, which was 2.2-fold and 3-fold lower than that found with AS and CPN treatments, respectively. On the contrary, highest $\mathrm{NH}_{4}^{+}{ }^{+15} \mathrm{~N}$ values were found in the top soil layer $(0-20 \mathrm{~cm})$ of $\mathrm{AS}$ and AS+DMPP amended soils (1.33 and $0.83 \mathrm{mg} \mathrm{kg} \mathrm{soil}^{-1}$, respectively) decreasing to an average value of $0.40 \mathrm{mg}$ $\mathrm{kg} \mathrm{soil}{ }^{-1}$ in both treatments in the second layer, and remaining almost constant with depth in the soil profile. Nevertheless, CPN exhibited the lowest $\mathrm{NH}_{4}^{+}{ }^{-15} \mathrm{~N}$ values $\left(0.07 \mathrm{mg} \mathrm{kg} \mathrm{soil}{ }^{-1}\right.$ on average), with no differences along the soil profile. It is worth mentioning, that the high sand content in soil $(67.4 \%)$ undoubtedly contributed to the recovery of fertilizer- ${ }^{15} \mathrm{~N}$ in $\mathrm{NH}_{4}^{+}$fraction in the bottom soil layers. ${ }^{15}$ Norganic mainly accumulated in the top soil layer $(0-20 \mathrm{~cm})$ in all treatments. No differences among treatments were recorded neither in top soil ( $0.86 \mathrm{mg} \mathrm{kg} \mathrm{soil}{ }^{-1}$, on average) nor from $20-40 \mathrm{~cm}$ soil layer downwards $\left(0.15 \mathrm{mg} \mathrm{kg} \mathrm{soil}^{-1}\right.$, on average).
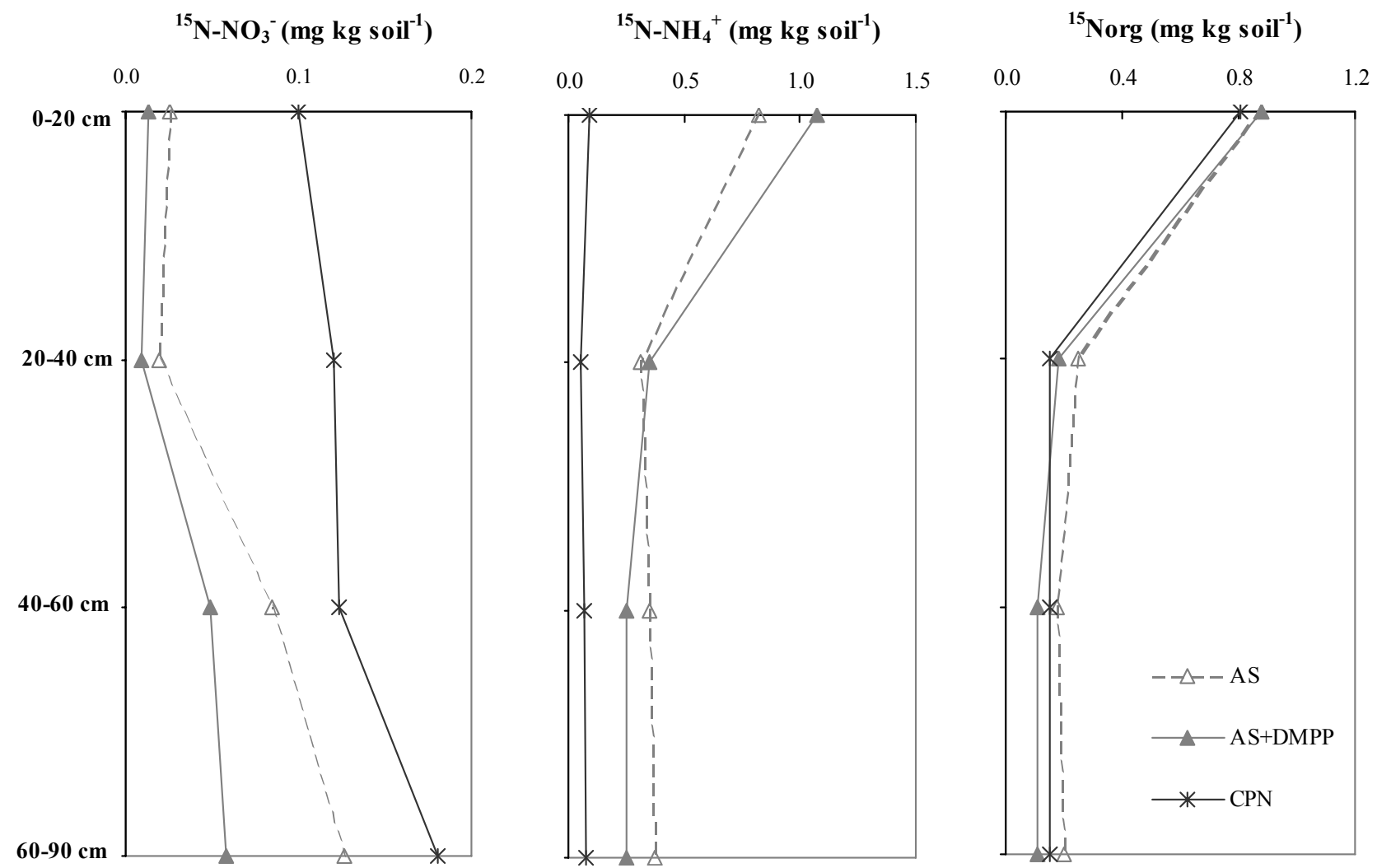

Figure 4. Fertilizer N concentrations in organic, nitrate and ammonium fraction in soil profile at the end of the experiment 


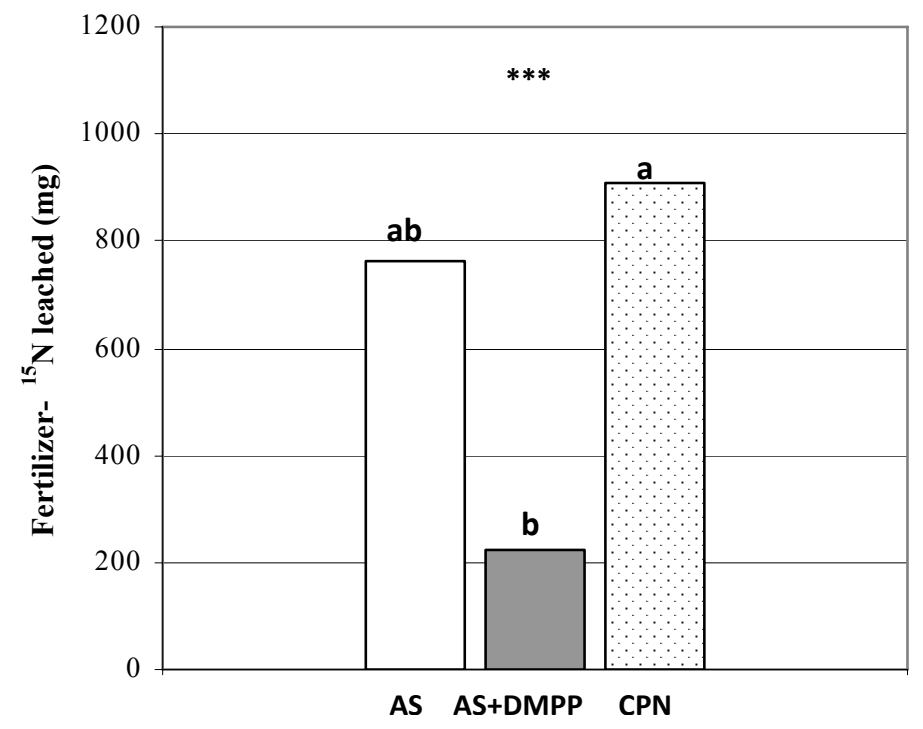

Figure 5. Total amount of fertilizer ${ }^{15} \mathrm{~N}$ leached at the end of the cycle

\subsection{Fertilizer ${ }^{15} \mathrm{~N}$ Recovery in the Plant-soil-drainage Solution System}

At the end of the study, $89 \%$ (on average) of the labelled fertilizer supplied along the cycle was recovered regardless $\mathrm{N}$ source (Table 4). The recovery of fertilizer $-{ }^{15} \mathrm{~N}$ in plant tissues, that is, the fertilizer $\mathrm{N}$ uptake efficiency (NUE) was highest in AS+DMPP treatment (69\%), with CPN and AS showing significantly lower values ( $61 \%$ and $54 \%$, respectively).

At the end of the study, a higher proportion of the fertilizer was retained in the soil of AS and AS+DMPP treatments $\left(22 \%\right.$ on average) than in those receiving CPN $(17 \%)$. Differences in the fertilizer $-{ }^{15} \mathrm{~N}$ partitioning among soil $\mathrm{N}$ pools according to $\mathrm{N}$ source were also recorded. An increased proportions of fertilizer ${ }^{15} \mathrm{~N}$ were recovered in soil $\mathrm{NH}_{4}^{+}$fraction of ammonium fertilized trees (11\% on average for AS and AS+DMPP) but the reverse was observed in $\mathrm{NO}_{3}^{-}$fraction, where $\mathrm{CPN}$ amended soils had the highest values $(6.3 \%)$. It is also noteworthy that in AS+DMPP amended soils, less than $2 \%$ of the applied ${ }^{15} \mathrm{~N}$ was recovered in $\mathrm{NO}_{3}^{-}$fraction, which represents a $47 \%$ decrease in the value recorded in AS amended soils.

The total amounts of $\mathrm{NO}_{3}^{-}{ }_{-}^{-15} \mathrm{~N}$ leached at the end of the study from CPN and AS amended soils were 4.0 and 3.4-fold higher respectively, than the values reported in AS+DMPP treatment. Thus, in CPN and AS fertilized soils, ${ }^{15} \mathrm{~N}$ losses to the drainage solution represented $9-10 \%$ of the total fertilizer applied but this value drastically decreased to less than $3 \%$ when the nitrification inhibitor DMPP was added.

\section{Discussion}

\subsection{Biomass and Fruit Yield}

Biomass growth of trees fertilized with the AS+DMPP exceeded that of AS and CPN fed trees. Enhanced biomass production when the nitrification inhibitor was added to conventional AS fertilizer has been previously reported by Serna et al. (2000) who found a more profuse development of leaves in young citrus trees grown in pots receiving AS+DMPP when compared to AS amended plants. However, these authors found no differences in biomass of other organs or in total tree growth. Studies carried out in olive trees revealed that the use of ammonium fertilizers plus DMPP increased the growth of the lateral branches and the number of buds (Muñoz-Guerra and Casar, 2008) compared to conventional ammonium fertilization. The explanation for the enhancement in biomass production of AS+DMPP fed trees was based not only in the diminished N losses from the soil profile, but also in the positive effect of the enhanced $\mathrm{NH}_{4}^{+} / \mathrm{NO}_{3}^{-}$nutrition in the presence of DMPP, as a consequence of the increased levels of $\mathrm{NH}_{4}^{+}$in the soil (Pasda et al., 2001). In this sense, it has been observed that $\mathrm{NH}_{4}^{+}$supply improves $\mathrm{N}$ nutrition in citrus (Serna et al., 1992) over $\mathrm{NO}_{3}^{-}$supply likely because plants spend less energy on $\mathrm{NH}_{4}^{+}$uptake than on $\mathrm{NO}_{3}^{-}$uptake (Ullrich, 1992; Wang et al., 1994) and absorbed $\mathrm{NH}_{4}^{+}$ can be used directly for amino acids metabolism. It also has been reported that $\mathrm{NH}_{4}^{+}$nutrition improves the availability of some micro nutrients (Tagliavini et al., 1995; Pasda et al., 2001), especially iron (Serna et al., 1992). Although Fe was not measured in the present study, Fe would have promoted tree development. Quiñones 
et al. (2009) found increased Fe concentrations in spring-leaves of AS+DMPP supplied trees when compared to AS fertilized trees. This effect of DMPP would become of extraordinary interest in the calcareous soils since some nutrients such as iron, are immobilized as a consequence of the elevated $\mathrm{pH}$.

In the present study, nitrate fed trees (CPN treatment) had a similar fruit yield than AS fertilized trees. Accordingly, Legaz et al. (1992) found no differences in fruit yield in a comparative study among ammonium sulphate, urea and calcium nitrate fertilized trees. However, Intrigliolo (1985) found increased three-year mean fruit yields in trees fertilized with calcium nitrate (104 kg fruit tree $\left.{ }^{-1}\right)$ when compared to ammonium sulphate (74 $\mathrm{kg}$ fruit tree ${ }^{-1}$ ) supplied trees. The same response has also been observed in young trees (Ishihara et al., 1977). In this study, the addition of the nitrification inhibitor resulted in higher fruit yield than that of AS and CPN treatments. There are no comparative studies between fertilization with nitrate and ammonium plus DMPP in trees; however, increases in crop yield of several herbaceous crops have been reported when DMPP was incorporated to ammonium fertilizers (Pasda et al., 2001). Hähndel and Zerulla (2001) found the same or higher fruit yield in fruit trees receiving an ammonium fertilization supplemented with DMPP when compared to control ammonium fertilized trees. In citrus trees, the use of nitrification inhibitors (i.e., nitrapyrin; 2,5-dichlorophenyl succinamic acid; DCD) also has been reported to increase fruit yields when compared to ammonium fertilizers (Liu et al., 1983; Serna et al., 1994). Rodríguez et al. (2011) obtained a three-year average fruit yield increase of $21 \%$ in a commercial orchard when DMPP was added to ammonium sulphonitrate. Nevertheless, Quiñones et al. (2009) found no differences in total yield when incorporating DMPP to AS and reported a significant increase in the number of fruits per tree. According to these authors, the enhanced activity of DMPP and hence the higher ammonium supply during spring months, could had been responsible for the more profuse fruit set. This result would be in accordance with the diminished biomass of abscised organs (mainly fruitlets and petals) reported in the present study.

\subsection{N Uptake in Plant Tissues}

Increasing $\mathrm{N}$ concentrations in woody organs and in total-tree average were obtained with the DMPP are consistent with the enhancement of $\mathrm{N}$ concentrations in spring-flush leaves of AN+DMPP supplied adult trees (Quiñones et al., 2009; Rodríguez et al., 2011). Thus, the results showed that total ${ }^{15} \mathrm{~N}$ uptake significantly increased with the addition of DMPP. Increases in N uptake through the use of DMPP have also been reported in some crops, i.e. wheat (Rodgers \& Ashworth, 1982), tomato (Somda et al., 1991), cotton (Rochester et al., 1996) and cabbage (Yu et al., 2008). Serna et al. (2000) obtained 1.7-fold increase in N uptake in young citrus trees grown in pots when DMPP was added to AS. This increase in N uptake in DMPP supplied plants, even higher than that of those receiving nitrate fertilization, could be explained as a result of the combined effect of: i) the more profuse development of root system in presence of the nitrification inhibitor; ii) the enhanced uptake of $\mathrm{N}$ in $\mathrm{NH}_{4}^{+}$over $\mathrm{NO}_{3}^{-}$when incorporating DMPP (Prasad \& Power, 1995; Serna et al., 1992); and iii) the reduction in $\mathrm{N}$ losses by leaching.

The pattern of ${ }^{15} \mathrm{~N}$-uptake allocation was affected by $\mathrm{N}$-source as evidenced by the differences in the aboveground/belowground $\mathrm{N}$ ratio. With $\mathrm{AS}$ and CPN fertilization, fertilizer-N was mainly allocated in aboveground organs, which is in accordance with previous reports (Feigenbaum et al., 1987; Quiñones et al., 2005; Martínez-Alcántara et al., 2012a). The AS+DMPP treatment showed the opposite pattern of greater allocation of $\mathrm{N}$ to below ground organs.

\subsection{Nitrate, Ammonium and Organic $N$ in Soil Profile}

The addition of the nitrate fertilizer (CPN) obviously led to the highest $\mathrm{NO}_{3}^{-}{ }_{-}{ }^{15} \mathrm{~N}$ concentrations during the studied period as a consequence of the continuous supply of nitrate-N. From the first sampling event onwards, a small amount of this supplied ${ }^{15} \mathrm{~N}\left(0.13 \mathrm{mg} \mathrm{kg}\right.$ soil ${ }^{-1}$ on average $)$ was recovered in the $\mathrm{NH}_{4}^{+}$fraction. Quiñones et al. (2007) and Martínez-Alcántara et al. (2012a) also reported that a small part of ${ }^{15} \mathrm{~N}$ supplied in nitric forms was fixed as interchangeable $\mathrm{NH}_{4}^{+}$. This can be explained by the process of inmobilization of fertilizer nitrate and later mineralization of ${ }^{15} \mathrm{~N}$-labeled soil organic matter. Davidson et al. (1991) found a rapid turnover of a small $\mathrm{NO}_{3}^{-}$pool in intact soil cores due to a rapid immobilization phase immediately following the addition of ${ }^{15} \mathrm{~N}$ tracers to soils, whereas Barraclough (1995) found a gross mineralization rate about 3-4 days after $\mathrm{N}$ immobilization.

The reverse pattern from that of CPN was observed with ammonium supplementation (as AS or AS+DMPP treatments). In the AS treatment, an increase in $\mathrm{NO}_{3}^{-}-{ }_{-}^{15} \mathrm{~N}$ concentrations was recorded between the 2 nd and 5 th soil sampling with a sharp decrease in $\mathrm{NH}_{4}^{+}{ }_{-}{ }^{15} \mathrm{~N}$ concentrations as a consequence of the rise of the nitrification processes. This phenomena was not observed in AS+DMPP soils which in fact, showed increased values of $\mathrm{NH}_{4}^{+}-{ }^{15} \mathrm{~N}$ as evidence of the inhibitory effect of DMPP on the nitrification process during this period. Quiñones 
et al. (2009) in a three-year study carried out in a citrus commercial orchard, found increased $\mathrm{NH}_{4}^{+}-\mathrm{N}$ concentrations (April-Nov) in both $0-20 \mathrm{~cm}$ and $20-40 \mathrm{~cm}$ layers of soils treated with AS+DMPP when compared to AS that was independent of the number of split applications. On the contrary, lower $\mathrm{NO}_{3}^{-}-\mathrm{N}$ concentrations were observed in DMPP treated soils. Serna et al. (2000) observed higher $\mathrm{NH}_{4}^{+}-\mathrm{N}$ and lower $\mathrm{NO}_{3}^{-}-\mathrm{N}$ concentrations not only when incorporating DMPP in an ammonium fertilizer, but also with dicyandiamide (Serna et al., 1994). It is remarkable, that in the present study, the significant differences among treatments in the $\mathrm{NO}_{3}^{-}-\mathrm{N}$ concentrations in the soils occurred from April to June (from 2nd to 4th soil sampling events) and thereafter, no differences were recorded. This result supports that reported by Quiñones et al. (2009) who only observed differences in the $\mathrm{NO}_{3}^{-}-\mathrm{N}$ fraction in the period ranging from $7^{\text {th }}$ April to $2^{\text {nd }}$ June. This was probably due to the fact that the capacity of DMPP to preserve nitrogen in ammonium form depends on several factors, such as soil temperature, humidity (Irigoyen et al., 2003), or soil texture (Barth et al., 2001). In particular, the effectiveness of DMPP decreases with increasing soil temperature (Ali et al., 2008; Slangen \& Kerkhoff, 1984; Zerulla et al., 2001; Irigoyen et al., 2003). Zerulla et al. (2001) observed that at $20^{\circ} \mathrm{C}$, ammonium disappeared completely from soil 2-3 months after DMPP application; Irigoyen et al. (2003) reported that DMPP become ineffective after one week at temperatures above $30^{\circ} \mathrm{C}$. The loss of DMPP effectiveness in the present study during the warm summer months, was not recovered for the rest of the experiment since fertilizer supplementation ended in October and only little amounts were supplied during this month. This could be responsible for the attenuated differences in $\mathrm{NH}_{4}^{+}-\mathrm{N}$ and $\mathrm{NO}_{3}^{-}-\mathrm{N}$ concentrations among treatments observed in the last sampling event. Serna et al. (2000) also observed a sharp decrease in $\mathrm{NH}_{4}^{+}-\mathrm{N}$ concentration, similar to that presented in this study, twenty days after last fertilization with ammonium sulphate nitrate either with or without DMPP. These authors also observed that all $\mathrm{NH}_{4}^{+}$supplied with DMPP was totally nitrified 60 days after fertilizer was applied.

\subsection{Leaching}

The total amount of $\mathrm{NO}_{3}^{-}{ }_{-}^{15} \mathrm{~N}$ leached from the AS+DMPP was much lower than that of AS or CPN treatments. This confirmed the effect of DMPP in reducing $\mathrm{N}$ loss by retaining applied $\mathrm{N}$ in the ammonium form and thus, delaying its nitrification and the opportunity to be leached. Wu et al. (2007) in a study carried on in filled-in soil polyvinylchloride columns, found that $22 \%$ (discounting the $\mathrm{N}$ leached in the control) of the $\mathrm{N}$ supplied as ammonium sulphate nitrate was leached 40 days later in a clay loam soil, whereas only $17 \%$ was leached when DMPP was added. Also, Yu et al. (2007a) found 57-63\% lower cumulative nitrate-N leaching losses when DMPP was added to urea fertilizer in an undisturbed heavy clay soil column experiment $(60 \mathrm{~cm} \mathrm{depth})$. In previous studies in citrus with no-labelled fertilizers, Serna et al. (2000) also obtained $57 \%$ less $\mathrm{NO}_{3}^{-}-\mathrm{N}$ in drainage water of young citrus plants grown in pots when DMPP was added to AS. These authors also observed a delay in $\mathrm{NO}_{3}^{-}$drainage such that in the presence of DMPP, the solubilisation of the $50 \%$ of fertilizer $\mathrm{NO}_{3}^{-}-\mathrm{N}$ took twice the time required in AS soils.

\subsection{N Recovery in Plant-soil-drainage Solution System}

At the end of the study, about $90 \%$ of the ${ }^{15} \mathrm{~N}$-fertilizer supplied was recovered, which implies that about $10 \%$ of this unaccounted for ${ }^{15} \mathrm{~N}$ was probably mainly lost via denitrification or $\mathrm{NH}_{3}$ volatilization. Although volatilization losses were not determined, they were likely minimal due to excellent soil permeability, good drainage conditions in the lysimieters and the small extra water irrigation fraction which was intended to move the fertilizer solution slightly below the ground surface after each fertigation event.

Total ${ }^{15} \mathrm{~N}$ uptake efficiencies (NUE) in this study (54-69\%), are similar to the $57 \%$ reported for mature citrus trees (Feigenbaum et al., 1987) grown in field conditions under drip irrigation supplied with ammonium nitrate. Syvertsen and Smith (1996) obtained NUE values for lysimeter-grown citrus trees in the order of $61-68 \%$. These data are similar to those reported by Quiñones et al. (2003) who found NUE values of 64 and $75 \%$ in potassium/calcium nitrate supplied trees grown in lysimeters under flood and drip irrigation, respectively. It is remarkable that higher NUE was obtained in nitrate than in ammonium (without DMPP) supplied trees, in the present study. This may be the consequence of the preferential uptake of nitrate- $\mathrm{N}$ forms in soil-grown citrus trees. According to Embleton et al. (1973), in well aerated soils with $\mathrm{pH}$ values close to neutral, $\mathrm{N}$ is mainly absorbed as nitrate since this ion is soluble in soil solution and easily transported to root zone. Ammonium fixation in the cation exchange positions and in the interlayers of 2:1 secondary phyllosilicates (vermiculite, illite and montmorillonite), however, would hamper its absorption (Feigenbaum et al., 1994). However, the addition of DMPP to the ammonium fertilizer increased this NUE to values even higher than that recorded in CPN fed trees. The more profuse development of root system together with the diminished leaching losses which significantly increased fertilizer- ${ }^{15} \mathrm{~N}$ uptake, were responsible for the higher NUE values obtained in presence of DMPP. In preliminary studies on the effectiveness of DMPP in young containerized citrus trees, increased NUE 
was obtained (calculated as the difference in total $\mathrm{N}$ content in unfertilized control and fertilized plants) in presence of DMPP (Serna et al., 2000). Nevertheless, there are no available data on the comparative NUE in ammonium with or without DMPP fertilized adult citrus trees.

At the end of this study, significantly lower ${ }^{15} \mathrm{~N}$ was retained in soil profile of CPN fertilized trees as a consequence of the increased leaching. This contrasted with the AS and AS+DMPP amended soils, which retained higher proportions of $\mathrm{N}$ especially in the ammonium fraction. The values of fertilizer- $\mathrm{N}$ recovery in the mineral $\mathrm{N}$ pools at the end of the growing cycle of CPN-supplied trees were similar to those reported in other studies on nitrate supplied trees (Feigenbaum et al., 1987; Martínez-Alcántara et al., 2012a). However, there are no available data on fertilizer- $\mathrm{N}$ recovery in nitrification inhibitor studies. Regarding $\mathrm{N}$ allocated in organic pool, about $8 \%$ on average of fertilizer ${ }^{15} \mathrm{~N}$ was immobilized in the organic matter. Values reported in the literature vary considerably, since this process seems closely dependent on soil organic matter content (Kee Kwong et al., 1986; Recous et al., 1988). Feigenbaum et al. (1987) found that in the upper $15 \mathrm{~cm}$ of the soil profile, $4.3 \%$ of the ${ }^{15} \mathrm{~N}$ applied was partitioned to the organic soil fraction nine months after $\mathrm{N}$-fertigation in a sandy soil. Nevertheless, Quiñones et al. (2005) in a sandy-loam-clay soil found that between $12 \%$ and $15 \%$ of the ${ }^{15} \mathrm{~N}$ applied accumulated in the organic soil $\mathrm{N}$ pool $(0-90 \mathrm{~cm}$ soil depth) at the end of the growing season.

\section{Conclusions}

The results of this study indicate that the addition of the nitrification inhibitor DMPP to ammonium sulphate in drip irrigated adult citrus trees, increased fertilizer-N uptake and fruit yield. $\mathrm{N}$ loss through leaching was markedly reduced as a consequence of the diminished nitrification rate. Therefore, the use of the nitrification inhibitor (DMPP) enabled a more efficient utilization of the fertilizer-N and in this way, the risk of nitrate-N pollution in shallow groundwater would be minimized. However DMPP supply should be considered during spring fertilization, since high temperatures of summer months significantly reduced its activity.

\section{References}

Ali, R., Iqbal, J., Tahir, G. R., \& Mahmood, T. (2008). Effect of 3,5-Dimethylpyrazole and nitrapyrin on nitrification under high soil temperature. Pak. J. Bot., 40(3), 1053-1062.

Allen, R. G., Pereira, L. S., Rae, D., \& Smith, M. (1998). Crop evapotranspiration (guidelines for computing crop water requirements). FAO Irrigation and Drainage Paper N 56 , FAO, Rome.

Alva, A. K., Paramasivam, S., \& Graham, W. D. (1998). Impact of nitrogen management practices on nutritional status and yield of Valencia orange trees and groundwater nitrate. J. Environ. Qual., 27, 904-910. http://dx.doi.org/10.2134/jeq1998.00472425002700040026x

Alva, A. K., Paramasivam, S., Graham, W. D., \& Wheaton, T. A. (2003). Best nitrogen and irrigation management practices for citrus production in sandy soils. Water Air Soil Poll., 143(1-4), 139-154. http://dx.doi.org/10.1023/A:1022883311070

Barraclough, D. (1995). ${ }^{15} \mathrm{~N}$ isotope dilution techniques to study soil nitrogen transformations and plant uptake. Fert. Research, 42, 185-192. http://dx.doi.org/10.1007/BF00750513

Barth, G., Tucher, S. V., \& Schmidhalter, U. (2001). Influence of soil parameters on the effect of 3,4-dimethylpyrazole phosphate as a nitrification inhibitor. Biol. Fertil. Soils, 34, 98-102. http://dx.doi.org/10.1007/s003740100382

Bergström, L., \& Brink, N. (1986). Effects of differential applications of fertilizer $\mathrm{N}$ on leaching losses and distribution of inorganic N in the soil. Plant Soil, 93, 333-345. http://dx.doi.org/10.1007/BF02374284

Bremner, J. M. (1996). Total nitrogen. In D. L. Sparks (Ed.), Methods of soil analysis (pp. 1085-1121) (Chapter 37). Part 3-chemical methods. American Society of Agronomy Inc.

Camargo, J. A., \& Alonso, A. (2006). Ecological and toxicological effects of inorganic nitrogen pollution in aquatic ecosystems: A global assessment. Environ. Int., 32(6), 831-849. http://dx.doi.org/10.1016/j.envint.2006.05.002

Cantarella, H., Mattos, D., Quaggio, J. A., \& Rigolin, A. T. (2003). Fruit yield of Valencia seet orange fertilized with different $\mathrm{N}$ sources and the loss of applied N. Nutr. Cycl. Agroecosys, 67(3), 215-223. http://dx.doi.org/10.1023/B:FRES.0000003600.20499.76

Castel, J. R., \& Buj, A. (1994). Growth and evapotranspiration of young, drip irrigated Clementine trees. Proc. 7th International Citrus Congress (Vol 2, pp. 651-656). Catania, Italy, March 8-13, 1992. 
Chaves, B., Opoku, A., De Neve, S., Boeckx, P., Van Cleemput, O., \& Hofman G. (2006). Influence of DCD and DMPP on soil N dynamics after incorporation of vegetable crop residues. Biol. Fert. Soils, 43, 62-68. http://dx.doi.org/10.1007/s00374-005-0061-6

Davidson, E. A., Hart, S. C., Shanks, C. A., \& Firestone, M. K. (1991). Measuring gross nitrogen mineralization, immobilization and nitrification by $15 \mathrm{~N}$ isotopic pool dilution in intact soil cores. J. Soil Sci., 42, 335-349. http://dx.doi.org/10.1111/j.1365-2389.1991.tb00413.x

Doorenbos, J., \& Pruitt, W. O. (1977). Crop water requirements. FAO Irrigation and Drainage Paper, $\mathrm{N}^{\circ} 24$, Rome.

Embleton, T. W., Reitz, H., \& Jones, W. W. (1973). Citrus fertilization. In W. Reuther (Ed.), Citrus Industry Univ. Calif. Div. Agric. Sci. Berkeley. Calif., 3, 122-182.

Feigenbaum, S., Bielorai, H., Erner, Y., \& Dasberg, S. (1987). The fate of ${ }^{15} \mathrm{~N}$ labelled nitrogen applied to mature citrus trees. Plant Soil, 97, 179-187. http://dx.doi.org/10.1007/BF02374940

Feigenbaum, S., Hadas, A., Sofer, M., \& Molina, J. A. (1994). Clay-fixed labeled ammonium as a source of $\begin{array}{lllllll}\text { available nitrogen. Soil Sci. Soc. } & \text { Am. } & \text { J., } & \text { 58, } & \text { 980-985. }\end{array}$ http://dx.doi.org/10.2136/sssaj1994.03615995005800030049x

Good, A. G., Shrawat, A. K., \& Muench, D. G. (2004). Can less yield more? Is reducing nutrient input into the environment compatible with maintaining crop production? Trends Plant Sci., 9, 597-605. http://dx.doi.org/10.1016/j.tplants.2004.10.008

Hähndel, R., \& Zerulla, W. (2001) Effects of ammonium-stabilized N-fertilizers on yield and quality of vegetables. Acta Hortic., 563, 81-86.

Hatch, D. J., Trindade, H., Cardenas, L. M., Carneiro, J., Hawkins, J. M. B., Scholefield, D., \& Chadwick, D. R. (2005). Laboratory study of the effects of two nitrification inhibitors on greenhouse gas emissions from a slurry-treated arable soil: impact of diurnal temperature cycle. Biol. Fert. Soils, 41(4), 225-232. http://dx.doi.org/10.1007/s00374-005-0836-9

Havlin, J. L., Beaton, J. D., Tisdale, S. L., \& Nelson, W. L. (2005). Soil fertility and fertilizers. In An introduction to nutrient management. Upper Saddle River, New Jersey: Pearson Education, Inc.

Hirel, B., Le Gouis, J., Ney, B., \& Gallais, A. (2007). The challenge of improving nitrogen use efficiency in crop plants: towards a more central role for genetic variability and quantitative genetics within integrated approaches. J. Exp. Bot., 58, 2369-2387. http://dx.doi.org/10.1093/jxb/erm097

Hodge, A., Robinson, D., \& Fitter, A. (2000). Are microorganisms more effective than plants at competing for nitrogen? Trends Plant Sci., 5, 304-308. http://dx.doi.org/10.1016/S1360-1385(00)01656-3

IAEA (International Atomic Energy Agency). (1983). A guide to the use of nitrogen-15 and radioisotopes in studies of plant nutrition: calculations and interpretation of data. Vienna.

Intrigliolo, F. (1985) Yield and nutrient responses of cv. Sanguinello Moscato orange to three types of nitrogen fertilizer. Rivista di Frutticoltura e di Ortofloricoltura, 47(5), 51-58.

Irigoyen, I., Muro, J., Azpilikueta, M., Aparicio-Tejo, P., \& Lamsfus, C. (2003). Ammonium oxidation kinetics in the presence of nitrification inhibitors DCD and DMPP at various temperatures. Aust. J. Soil. Res., 41, 1177-1183. http://dx.doi.org/10.1071/SR02144

Ishihara, M., Konno, S., \& Takatsuji, T. (1977). Effects of nitrate and ammonium fertilizers on the growth, mineral composition, bearing and fruit quality of young satsumas. Bull. Fruit Tree Res. Stat. (Hiratsuka, Kanagawa, Japan), 4, 67-79.

Kato, T., \& Kubota, S. (1982) Reduction and assimilation of ${ }^{15} \mathrm{~N}$-nitrate by citrus trees in cold season in comparison with summer. J. Japan Soc. Hort. Sci., 50(4), 413-420.

Kee, K., Wong K. F., Deville, J., Cavalot, P. C., \& Riviere, V. (1986). Biological immobilisation of fertiliser nitrogenin humid tropical soils of Mauritius. Soil Sci., 141, 195-199.

Keller, J., \& Karmelli, D. (1974) Trickle irrigation design parameters. T. ASAE, 17(4), 678-684.

Kubota, S., Kato, T., Akao, S., \& Bunya, C. (1976a). ${ }^{15} \mathrm{~N}$ absorption and translocation by Satsumas mandarin trees. III. Behaviour of nitrogen supplied in early spring. Bull. Shikoku Agric. Exp. Stn., 29, 49-54.

Kubota, S., Kato, T., Akao, S., \& Bunya, C. (1976b). ${ }^{15} \mathrm{~N}$ absorption and translocation by Satsumas mandarin trees. IV. Behaviour of nitrogen supplied in early summer. Bull. Shikoku Agric. Exp. Stn., 29, 55-66. 
Lea-Cox, J. D., \& Syvertsen, J. P. (1996). How nitrogen supply affects growth and nitrogen uptake, use efficiency, and loss from Citrus seedlings. J. Am. Soc. Hort. Sci., 121(1), 105-114.

Lea-Cox J. D., Syvertsen, J. P., \& Graetz, D. A. (2001). Springtime ${ }^{15} \mathrm{~N}$ uptake, partitioning, and leaching losses from young bearing citrus trees of differing nitrogen status. J. Am. Soc. Hort. Sci., 126(2), 242-251.

Legaz, F., Serna, M. D., \& Primo-Millo, E. (1992). Effectiveness for the $\mathrm{N}$ form applied by a drip irrigation system to citrus. Proc. Int. Soc. Citriculture, 590-592.

Li, J. S., Zhang, J. J., \& Ren, L. (2003). Water and nitrogen distribution as affected by fertigation of ammonium nitrate from a point source. Irrigation Sci., 22, 19-30.

Linzmeier, W., Gutser, R., \& Schmidhalter, U. (2001). Nitrous oxide emission from soil and from a nitrogen $15 \mathrm{~N}$-labelled fertilizer with the new nitrification inhibitor 3,4-dimethylpyrazole phosphate (DMPP). Biol. Fertil. Soils, 34(2), 103-108. http://dx.doi.org/10.1007/s003740100383

Liu, Z. S., Qiu, Q. F., Chen, S. H., Lin, L. K., Li, Z. F., Chen, G. Q., \& Zu, B. (1983). A study of nitrification inhibitor application to citrus. Application of Atomic Energy in Agriculture, 2, 31-37.

Lyle, P., \& Richard, G. (1997) Nitrate leaching using two potato-corn N-fertilizer plans on sandy soil. Agr. Ecosyst. Environ., 65, 1-13.

Martínez, J. M., Bañuls, J., Quiñones, A., Martín, B., Primo-Millo, E., \& Legaz, F. (2002) Fate and transformation of ${ }^{15} \mathrm{~N}$ labelled applied in spring to Citrus trees. J. Hort. Sci. Biotech., 77, 361-367.

Martínez-Alcántara, B., Quiñones, A., Legaz, F., \& Primo-Millo, E. (2012a). Nitrogen-use efficiency of young citrus trees as influenced by the timing of fertilizer application. J. Plant Nutr. Soil Sci., 175(2), 282-292. http://dx.doi.org/10.1002/jpln.201100223

Martínez-Alcántara, B., Quiñones, A., Primo-Millo, E., \& Legaz, F. (2012b). Seasonal changes in nitrate uptake efficiency in young potted citrus trees. J. Agr. Sci., 4(8), 11-19. http://dx.doi.org/ 10.5539/jas.v4n8p1 1

Mattos, D. Jr., Graetz, D. A., \& Alva, A. K. (2003). Biomass distribution and nitrogen-15 partitioning in citrus trees on a sandy Entisol. Soil Sci. Soc. Am. J., 67, 555-563. http://dx.doi.org/10.2136/sssaj2003.0555

McNeal, B. L., Stanley, W. D., Gilreath, P. R., Downey, D., \& Creighton, F. J. (1995) Nutrient-loss trends for vegetable and citrus fields in West-Central Florida: I. Nitrate. J. Environ. Qual., 24, 95-100. http://dx.doi.org/10.2134/jeq1995.00472425002400010013x

McCarty, G. W. (1999). Modes of action of nitrification of inhibitors. Biol. Fertil. Soils, 29, 1-9. http://dx.doi.org/10.1007/s003740050518

McCarty, G. W., \& Bremner, J. M. (1989). Inhibition of nitrification in soils by heterocyclic nitrogen compounds. Biol. Fertil. Soils, 8, 204-211. http://dx.doi.org/10.1007/BF00266480

Morgan, K. T., \& Hanlon, E. A. (2006). Improving Citrus Nitrogen Uptake Efficiency: Linking citrus irrigation management to citrus fertilizer practices. Retrieved from http://edis.ifas.ufl.edu/SS466

Morgan, K. T., Wheaton, T. A., Castle, W. S., \& Parsons, L. R. (2009). Response of young and maturing citrus trees grown on a sandy soil to irrigation scheduling, nitrogen fertilizer rate, and nitrogen application method. Hort. Sci., 44, 145-150.

Muñoz-Guerra, L., \& Casar, C. (2008). Benefits of the mixed ammonium/nitrate nutrition in olive trees: use of 3,4-dimethylpirazole phosphate plant nutrition products. VI International ISHS Symposium on Mineral Nutrition of Fruit Crops, Portugal, Book of abstracts (p. 377).

Parsons, L. R. (1989). Management of micro-irrigation systems for Florida citrus. Fruit Crops Fact Sheet. Univ. of Florida Coop. Ext. Serv. FC-81. Univ. of Florida, Gainesville.

Pasda, G., Händel, R., \& Zerulla, W. (2001). Effect of fertilizers with the new nitrification inhibitor DMPP on yield and quality of agricultural and horticultural crops. Biol. Fertil. Soils, 34, 85-97. http://dx.doi.org/10.1007/s003740100381

Prasad, R., \& Power, J. F. (1995). Nitrification inhibitors for agriculture, health, and the environment. $A d v$. Agron., 54, 233-281. http://dx.doi.org/10.1016/S0065-2113(08)60901-3

Quiñones, A., Bañuls, J., Primo-Millo, E., \& Legaz, F. (2003). Effects of ${ }^{15} \mathrm{~N}$ application frequency on nitrogen uptake efficiency in citrus trees. J. Plant Physiol., 160, 1429-1434. http://dx.doi.org/10.1078/0176-1617-01018 
Quiñones, A., Bañuls, J., Primo-Millo, E., \& Legaz, F. (2005). Recovery of the 15N-labelled fertiliser in citrus trees in relation with timing of application and irrigation system. Plant Soil, 268, 367-376. http://dx.doi.org/10.1007/s11104-004-0337-x

Quiñones, A., Martínez-Alcántara, B., \& Legaz, F. (2007). Influence of irrigation system and fertilization management on seasonal distribution of $\mathrm{N}$ in the soil profile and on N-uptake by citrus trees. Agric. Ecosys. Env., 122, 399-409. http://dx.doi.org/10.1016/j.agee.2007.02.004

Quiñones, A., Martínez-Alcántara, B., \& Legaz, F. (2009). Improvement of $\mathrm{N}$ fertilization by using the nitrification inhibitor (DMPP) in drip-irrigated citrus trees. Span. J. Agric. Res., 7(1), 190-199.

Quiñones, A., Martínez-Alcántara, B., Martínez, J. M., Forner-Giner, M. A., Iglesias, D. J., Primo-Millo, E., \& Legaz, F. (2012). Fate of ${ }^{15} \mathrm{~N}$ labelled potassium nitrate in different citrus cultivated soils: influence of spring and summer application. Water Air Soil Pol., 223, 2209-2222. http://dx.doi.org/10.1007/s11270-011-1017-0

Raigón, M. D., Pérez-García, M., Maquieira, A., \& Puchades, R. (1992). Determination of available nitrogen (nitric and ammoniacal) in soils by flow injection analysis. Analysis, 20, 483-487.

Recous, S., Machet, J. M., \& Mary, B. (1988). The fate of labelled 15N urea and ammonium nitrate applied to a winter wheat crop. I. Nitrogen transformations in the soil. Plant Soil, 112, 205-214. http://dx.doi.org/10.1007/BF02139997

Rochester, I. J., Constable, G. A., \& Saffigna, P. G. (1996). Effective nitrification inhibitors may improve fertilizer recovery in irrigated cotton. Biol. Fertil. Soils, 23, 1-6. http://dx.doi.org/10.1007/BF00335810

Roco, M. M., \& Blu, R. O. (2006) Evaluation of the nitrification inhibitor 3,4-dimethyl pyrazole phosphate in two Chilean soils. J. Plant Nutr., 29, 521-534. http://dx.doi.org/10.1080/01904160500526584

Rodríguez, V. A., Alayón, P., Píccoli, A. B., Mazza, S. M., \& Martínez, G. C. (2011). 3,4-Dimethylpyrazole phosphate (DMPP) efficiency in sweet orange in Argentina northeast (in spanish). Rev. Bras. Frutic., 33(4), 1344-1349. http://dx.doi.org/10.1590/S0100-29452011000400035

Serna, M. D., Borrás, R., Legaz, F., \& Primo-Millo, E. (1992) The influence of nitrogen concentration and ammonium/nitrate ratio on N-uptake, mineral composition and yield citrus. Plant Soil, 147, 13-23. http://dx.doi.org/10.1007/BF00009366

Serna, M. D., Legaz, F., \& Primo-Millo, E. (1994). Efficacy of Dicyandiamide as a soil nitrification inhibitor in $\begin{array}{llllll}\text { citrus production. Soil Sci. Soc. } A m . \quad J ., & 58(6), & \text { 1817-1824. }\end{array}$ http://dx.doi.org/10.2136/sssaj1994.03615995005800060034x

Serna, M. D., Bañuls, J., Quiñones, A., Primo-Millo, E., \& Legaz, F. (2000). Evaluation of 3,4-dimethylpyrazole phosphate as a nitrification inhibitor in a Citrus-cultivated soil. Biol. Fertil. Soils, 32, 41-46. http://dx.doi.org/10.1007/s003740000211

Shen, Q. R., Ran, W., \& Cao, Z. H. (2003). Mechanisms of nitrite accumulation occurring in soil nitrification. Chemosphere, 50, 747-753. http://dx.doi.org/10.1016/S0045-6535(02)00215-1

Slangen, J. H. G., \& Kerkhoff, P. (1984). Nitrification inhibitors in agriculture and horticulture: A literature review. Fert. Res., 5, 1-76. http://dx.doi.org/10.1007/BF01049492

Smajstrala, A. G., Harrison, D. S., Zazutta, F. S., Parsons, L. R., \& Stone, K. C. (1987). Trickle irrigation scheduling for Florida citrus. Bull. 208. Florida Coop. Ext. Serv., Inst. Food and Agric. Sci., Univ. of Florida, Gainesville.

Somda, Z. C., Phatak, S. C., \& Mills, H. A. (1991). Influence of biocides on tomato nitrogen uptake and soil nitrification and denitrification. $J . \quad$ Plant Nutr., 14, 1187-1199. http://dx.doi.org/10.1080/01904169109364277

Syvertsen, J. P., \& Smith, M. L. (1996). Nitrogen uptake efficiency and leaching losses from lysimeter-grown Citrus trees fertilized at three nitrogen rates. J. Am. Soc. Hort. Sci., 121(1), 57-62.

Tagliavini, M., Masia, A., \& Quartieri, M. (1995). Bulk soil pH rhizosphere $\mathrm{pH}$ of peach trees in calcareous and alkaline soils as affected by the form of nitrogen fertilizers. Plant Soil, 176(2), 263-271. http://dx.doi.org/10.1007/BF00011790

Trenkel, M. E. (1997). Controlled release and Stabilized Fertilisers in Agriculture. IFA, Paris. 
Ullrich, W. R. (1992). Transport of nitrate and ammonium through plant membranes. In K. Mengel, \& D. J. Pilbeam (Eds.), Nitrogen metabolism of plants (pp. 121-137). Oxford Science, Clarendon Press, Oxford.

Wang, M. Y., Glass, A. D. M., Shaff, J. E., \& Kochian, L. V. (1994). Ammonium uptake by rice roots. III. Electrophysiology. Plant Physiol., 104, 899-906.

Weiske, A., Benckiser, G., Herbert, T., \& Ottow, J. C. G. (2001). Influence of the nitrification inhibitor 3,4-domethypyrazole phosphate (DMPP) in comparison to dicyandiamide (DCD) on nitrous oxide emissions, carbon dioxide fluxes and methane oxidation during 3 years of repeated application in field experiments. J. Biol. Fertil. Soils, 34(2), 109-117. http://dx.doi.org/10.1007/s003740100386

Wu, S. F., Wu, L. H., Shi, Q. W., Wang, Z. Q., Chen, X. Y., \& Li, Y. S. (2007). Effects of a new nitrification inhibitor 3,4-dimethylpyrazole phosphate (DMPP) on nitrate and potassium leaching in two soils. $J$. Environ. Sci., 19, 841-847. http://dx.doi.org/10.1016/S1001-0742(07)60140-5

Xing, G. X., \& Zhu, Z. L. (2000). An assessment of $\mathrm{N}$ loss from agricultural fields to the environment in China. Nutr. Cycl. Agroecosys., 57, 67-73. http://dx.doi.org/10.1023/A:1009717603427

Yu, Q., Chen, Y., Ye, X., Tian, G., \& Zhang, Z. (2007a). Evaluation of nitrification inhibitor 3,4-dimethyl pyrazole phosphate on nitrogen leaching in undisturbed soil columns. Chemosphere, 67, 872-878. http://dx.doi.org/10.1016/j.chemosphere.2006.11.016

Yu, Q., Chen, Y., Ye, X., Tian, G., \& Zhang, Z. (2007b). Influence of the DMPP (3,4-dimethyl pyrazole phosphate) on nitrogen transformation and leaching in multi-layer soil columns. Chemosphere, 69, 825-831. http://dx.doi.org/10.1016/j.chemosphere.2007.05.047

Yu, Q., Ye, X., Chen, Y., Zhang, Z., \& Tian, G. (2008). Influences of nitrification inhibitor 3,4-dimethyl pyrazole phosphate on nitrogen and soil salt-ion leaching. $J$. Environ. Sci., 20, 304-308. http://dx.doi.org/10.1016/S1001-0742(08)60048-0

Zerulla, W., Barth, T., Dressel, J., Erhardt, K., von Locquenghien, K. H., Pasda, G., Rädle, M., \& Wissemeier, A. H. (2001). 3,4-Dimethylpyrazole phosphate (DMPP)-a new nitrification inhibitor for agriculture and horticulture. Biol. Fert. Soils, 34, 79-84. http://dx.doi.org/10.1007/s003740100380 